This manuscript is a preprint and has been submitted for publication in Nature Reviews Earth \& Environment. Please note that the manuscript has not yet undergone peer review. Subsequent versions of this manuscript may have slightly different content. If accepted, the final version of this manuscript will be available via the 'Peerreviewed Publication DOl' link on the right-hand side of this webpage. Please feel free to contact any of the authors; we welcome feedback. 


\title{
Geodynamics of continental rift initiation and evolution
}

\author{
Sascha Brune (GFZ Potsdam, University Potsdam, Germany) \\ Folarin Kolawole (BP/LDEO, Columbia University, USA) \\ Jean-Arthur Olive (Ecole Normale Supérieure / CNRS UMR 8538, Paris, France) \\ D. Sarah Stamps (Virginia Tech, USA) \\ W. Roger Buck (LDEO, Columbia University, USA) \\ Susanne J.H. Buiter (RWTH Aachen, Germany)
}

\section{Key Points}

- Rift inception and evolution is controlled by a spatial and temporal competition between tectonic drivers, resisting factors and weakening processes.

- Continental rifting is an intrinsically transient process involving distinct evolution phases that overprint each other.

- Weakening feedbacks act on a shorter time scale than variations in driving forces and therefore exert key control on rift success.

- Failed rifts should be considered dormant rather than dead as they may get reactivated when the local force balance changes.

- Understanding rift processes is crucial for identifying seismic hazards and the distribution of georesources in rifts worldwide.

\begin{abstract}
A rift is a nascent plate boundary where the continental lithosphere is extended and possibly broken. In this review, we focus on fundamental rift processes and how they evolve through time. We aim at providing a modular overview of the driving forces, resisting factors, and weakening processes as well as how their interaction generates the large variety of rifts on Earth. Rifting initiates when the joint contribution of lithospheric buoyancy forces, mantle tractions, and subduction-related forces overcome the lithospheric strength. Subsequently, rifting is facilitated by softening mechanisms, such as frictional weakening, diking and surface processes, but also by inherited rheological weaknesses, such as those coinciding with currently active rifts in East Africa. These positive feedback effects may however be counterbalanced by dynamic processes resisting deformation such as isostatic forces or lithospheric cooling, which may ultimately lead to the abandonment of a rift. A fundamental understanding of the force balance in rifts is required to assess their controls on rift-wide stress fields, which is essential when georesources like geothermal energy are to be exploited in a responsible way. These cross-scale interactions can only be understood through multidisciplinary approaches that integrate geophysical and geochemical data with modern modelling techniques.
\end{abstract}




\section{Introduction}

Continental rifts are emergent plate boundaries where the lithosphere gets thinned, where the crust is broken and where melting and magmatism occurs until eventually a new ocean basin might form. These geological processes induce a strong economical and societal relevance of rifts. Subsurface water reservoirs in rifts may feature anomalously high temperatures, making them prime targets for geothermal energy generation ${ }^{1}$. Surface depressions of rifts create accommodation space for sedimentary basins, which may hold sediment-hosted ore deposits $^{2,3}$ like zinc, lead and copper that are of strategic relevance for implementing the global energy transition through metal-intensive green technologies ${ }^{4}$ (e.g. solar photovoltaic, wind turbines). Rift sediments as well as rift basalts and peridotites show great potential for carbon capture and storage ${ }^{5}[\mathrm{G}]$. This is in ironic contrast to the fact that rifts and rifted margins have traditionally been heavily exploited for hydrocarbons ${ }^{6}$. Finally, rift processes may exhume mantle rocks whose chemical alteration leads to the creation of natural hydrogen [G]. Whether past or present rifts can serve as an economically viable source of hydrogen is still unclear, but currently investigated ${ }^{7}$. In contrast to these positive examples, rifts also pose considerable hazards ranging from natural earthquake activity ${ }^{8}$, volcanism ${ }^{9}$ to large-scale carbon dioxide degassing ${ }^{10}$ and landslides ${ }^{11}$. Understanding the cross-scale links between the geodynamic processes that control rift initiation and evolution hence also holds relevance for sustainable and safe utilisation of rift environments.

Continental rifts and rifted margins have often been classified in terms of their geometry ${ }^{12}$, the amount of sedimentation ${ }^{6}$ and magmatism ${ }^{13}$. These categories, however, apply only to a given moment while recent surveys, models and concepts show that rift dynamics can change dramatically through time. Magma-poor rifts for example can turn into magmatic rifts, such as the Norwegian-Greenland margins ${ }^{14}$ and the Southern South Atlantic ${ }^{15}$, in particular upon the impingement of a mantle plume ${ }^{16,17}[\mathrm{G}]$. Also it has become clear that the classical rift typecasts of wide and narrow rifts ${ }^{18}$ can not be directly linked to wide and narrow rifted margins, as laterally migrating narrow rifts can indeed generate a wide continental margin ${ }^{19,20}$. Finally, many rifts do not evolve into a rifted margin. In these so-called failed rifts tectonic activity has eventually ceased before continental rupture was complete ${ }^{6}$. In extending existing rift classifications to a process-based view, it is equally important to analyse the reasons for rift failure as deducing the causes for success.

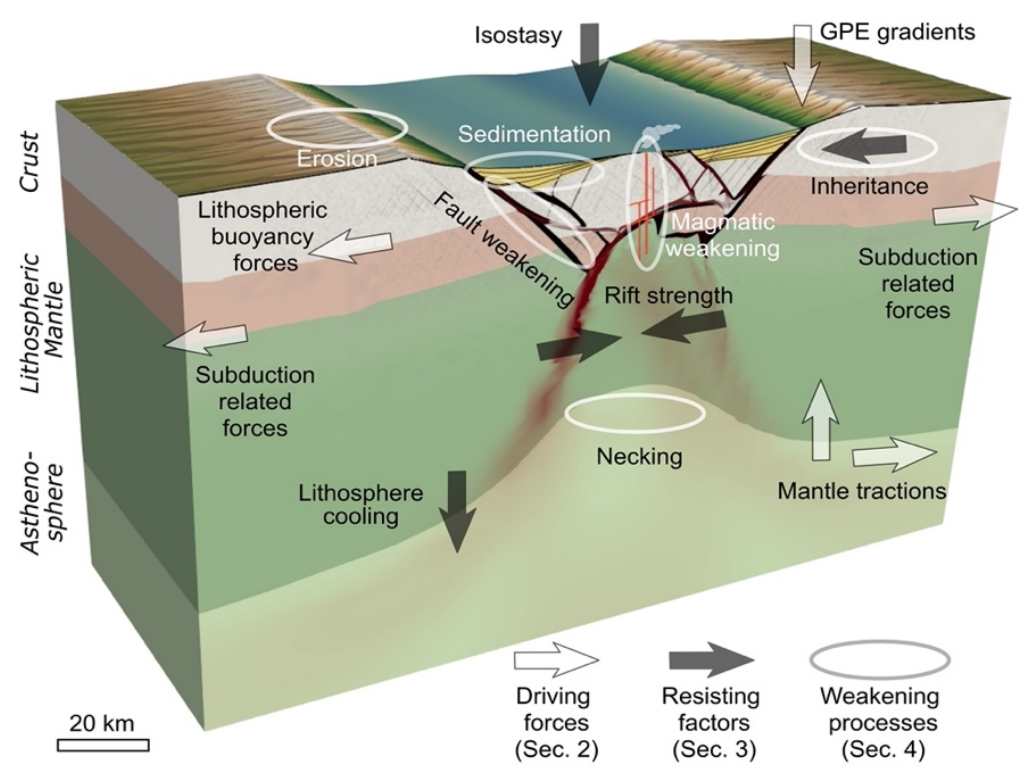

Fig. 1 | Key processes and forces controlling rift dynamics. Continental rifts are affected by a multitude of processes ranging from grain scale deformation in ductile shear zones and plate boundary-scale faults to plate-scale drivers of deformation. We describe these factors and their interaction in terms of driving forces (Sec. 2), resisting factors (Sec. 3) and weakening processes (Sec. 4). Image based on a numerical forward model from Ref. ${ }^{21}$. 


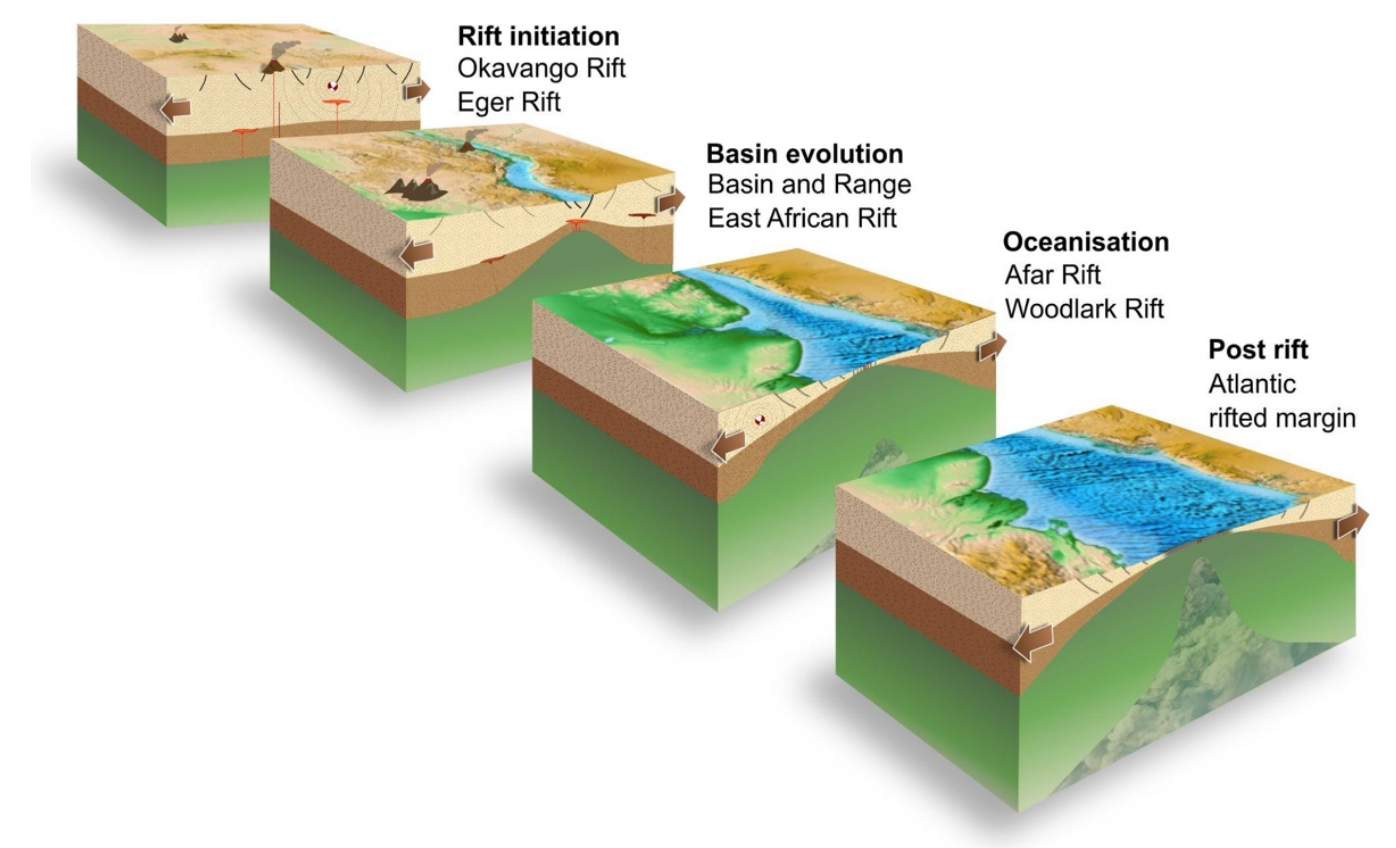

Box 1 | Conceptual model for the inception and evolution of continental rifts.

Breaking the continental lithosphere is an intrinsically transient process. Rifting hence progresses continuously, involving several major phases.

Rift initiation. Rifts localise when tensional stresses exceed the strength of the continental lithosphere. Deformation can be accommodated by brittle faults, ductile shear zones, and magmatic dikes. Incipient rifting occurs for instance at the Okavango Rift in the south-eastern termination of the East African Rift and in the Central European Eger Rift. Structures inherited from previous deformation episodes often facilitate and guide deformation.

Basin evolution. Neighbouring faults compete and ultimately coalesce into an array of dominant faults. The strike-perpendicular extent of a rift can vary from less than hundred kilometres in narrow rifts, such as the Main Ethiopian Rift in East Africa, to several hundred kilometres in wide rifts, like in the Basin and Range region of North America. Slip along major faults and ductile thinning of the lower lithosphere causes hanging wall subsidence, which creates sedimentary basins. Hot, sublithospheric mantle (i.e. asthenosphere) rises in response to lithospheric thinning and causes decompression melting. These melts migrate rapidly through the lithosphere generating dikes, sills, and volcanoes.

Oceanisation. When the crust is thinned sufficiently, deformation progressively focusses migrating towards the location of future break-up. Enhanced decompression melting at a successively larger depth range intensifies magmatic emplacement in the rift centre. Eventually, magmatic segments may accommodate most extensional deformation, such as in the Afar region in East Africa or the Woodlark Rift in southeastern Papua New Guinea. When the continental lithosphere is separated and replaced by upwelling mantle and basaltic melt intrusions, the transition to mid-ocean spreading takes place.

Post rift. Once the newly formed mid-ocean ridge accommodates all plate divergence, the former rift turns into a rifted continental margin. This margin, however, continues to deform: on the one hand, proximal [G] and distal [G] parts of the margin cool at different rates, causing the distal part to subside slightly faster, leading to margin tilting. On the other hand, sediments transported by onshore river networks may load the proximal margin inducing subsidence. Additional processes, like along-shore sediment transport or glacial loading and unloading as in the North Atlantic, continue to shape rifted margins long beyond the original rift phase. 
The processes driving continental rifts and shaping their surface expressions can only be understood through multidisciplinary approaches. These efforts comprise classical geological mapping ${ }^{22,23}$, geophysical surveys for imaging deep rift structures ${ }^{24,25}$, geodetic surveys to identify current plate kinematics ${ }^{26}$, and major drilling campaigns ${ }^{27,28}$. Advances in the field of igneous petrology ${ }^{29}$ and thermochronology ${ }^{30}$ allow for detailed tracking of rift activity through time ${ }^{31-33}$. This wealth of information has been integrated in plate kinematic reconstructions ${ }^{34,35}$, which provide high-resolution quantitative models from the onset of rifting to mature ocean basins. Finally, the development of analytical ${ }^{36,37}$, analogue ${ }^{38,39}$, and numerical ${ }^{40,41}$ modelling approaches provide an impactful way to integrate observational data and fundamental physical laws within one framework. These advances allow for an unprecedented understanding of the tectonic drivers of rifting.

Here we review key factors and processes affecting rift tectonics and how they evolve through time (Fig. 1). Instead of a structural template, we aim at providing a modular review of the driving forces [G], resisting factors [G], and weakening processes [G]. This approach is particularly useful for rifts, since in contrast to most other plate boundaries like subduction zones and mid-ocean ridges, rifts can never achieve a quasi steady-state configuration (Box 1). In contrast, the balance between driving forces and resisting strength evolves continuously, which shapes the characteristic normal faults, sedimentary basins and magmatic features documented in presently active rifts, failed rifts and rifted margins worldwide.

\section{Driving forces}

Forces arising in several ways may drive lithospheric rifting and we group them into three categories: lithospheric buoyancy forces, mantle tractions, and subduction-related forces (Fig. 2). Below we describe these three categories and how they relate to rifting processes. Evidence strongly suggests that lithospheric buoyancy forces (Fig. 2B) contribute to rifting in some settings, while the relative roles of mantle tractions [G] (Fig. 2C) and subduction-related forces (Fig. 2D) has been debated for decades. The types of forces can be related, as for example, when upwelling of a hot mantle plume (via mantle traction) generates dynamic uplift (Fig. 2C, right). The heat supplied by the plume can eventually thin the lithosphere causing uplift due to what we term a lithospheric buoyancy force.

\subsection{Lithospheric buoyancy forces}

Lithospheric buoyancy forces arise from lateral variations in topography and lithospheric structure, which generate stresses from gravitational potential energy (GPE) [G] gradients within the lithosphere that drive lithospheric deformation ${ }^{42-44}$. Topography variations are partially supported by vertical tractions from mantle flow and are discussed in Sec. 2.2. Lithospheric structure variations arise from heterogeneities in crustal thickness (Fig. 2B, left), lithospheric thickness (Fig. 2B, right), temperature, composition, and density.

An example where lithospheric buoyancy forces due to elevated topography dominate the force balance driving rifting is the East African Rift System. The high topography is partially supported by vertical mantle tractions. A recent geodynamic investigation of the continental East African Rift System uses 3D computational modelling to suggest lithospheric buoyancy forces are the main driver of large-scale east-west extension that is constrained by geodetic observations $^{45}$ (Fig. 3). This work supports previous 2D modelling ${ }^{46-48}$ and 3D modelling approaches $^{49,49}$ that estimate $10-15 \mathrm{MPa}$ of stress from lateral variations in topography and density heterogeneities.

Crustal thickening produces extensional stresses and this is likely driving the broad region of extension of the Basin and Range Province in the western United States where paleoelevation data have been used to quantify GPE gradients ${ }^{50}$. The collapse of regions of thick crust has also been suggested as a cause of the broad zones of rifting inferred to have occurred in West 
Antarctica ${ }^{51,52}$. In these cases where lithospheric buoyancy forces dominate rifting, the rift systems are largely isolated from active subduction zones. Each example is also affected by elevated topography either in the present (East Africa) or in the recent past (Basin and Range, West Antarctica), thus GPE gradients have played an important role in their rift dynamics.

\subsection{Mantle tractions}

Convection and density variations in the sub-lithospheric mantle can affect the mantle tractions that drive plate tectonics in general and rifting specifically. Here, we describe mantle tractions that act normal to and parallel to the base of the lithosphere as vertical and horizontal tractions, respectively. Horizontal tractions result when the asthenosphere moves laterally relative to the overlying lithosphere. The horizontal traction on a plate is given by integrating basal shear stresses [G] over area.

\subsubsection{Horizontal tractions}

The magnitude of horizontal tractions on plates is disputed. If mantle convection cells are small compared to tectonic plates then one would assume that horizontal tractions slow the motion of the plate. This idea combined with the fact that the largest plate, the Pacific plate, moves faster than other plates led several groups to conclude that horizontal tractions are negligible ${ }^{53,54}$. In contrast, global models of plate motions ${ }^{55}$ conclude that horizontal tractions help drive plate motions and rifting. At a global scale, the interaction of cratonic roots with the convecting mantle plays an important role in the relative role of horizontal tractions on the lithosphere ${ }^{56}$. Thus, it is theoretically possible that horizontal tractions could play an important role in rift settings where cratonic roots exist, although this process has not been demonstrated conclusively.

\subsubsection{Vertical tractions}

Vertical tractions are produced by sub-lithospheric lateral density variations that drive mantle convection, which we separate into normal stress and lateral pressure variations. Normal stresses are generated by vertical gradients in vertical velocity where convective upwellings or downwellings meet the lithosphere. Pressure variations at the top of convecting mantle also contribute to vertical tractions. The topography produced by vertical tractions below the lithosphere is termed dynamic topography ${ }^{57,58}$. It is dynamic since the relief is produced by flow of the mantle.

The magnitude of dynamic topography is difficult to measure, and the best ways to estimate it are controversial ${ }^{59,60}$. Straightforward estimates of the amplitude and wavelength of dynamic topography come from regions where there are good geophysical constraints on isostatic topography. This approach assumes that dynamic topography is what is left when the estimated isostatic topography is removed from the observed topography. The ocean basins offer a relatively homogeneous and geophysically well-characterised example region to study dynamic topography. Isostatic topography was recently calculated using an extensive dataset of seismic constraints on crustal thickness and lithospheric density variation in oceanic lithospheric lithosphere ${ }^{58}$. This study concludes that the magnitude of dynamic depth variations in the ocean basins is +/- $1000 \mathrm{~m}$ which translates to +/-700 dynamic topography without water loading. This uplift could result in about $3 \mathrm{TN} / \mathrm{m}$ of extensional line force [G].

Dynamic uplift in rift settings is inferred over many regions where mantle plumes have been identified in the present and in the past, which are areas of mantle upwelling and melting ${ }^{61}$ (Fig. 2C, right). The association of large plume-related flood basalt outpouring with major rifting events, indicates an important role of plumes in producing the vertical and horizontal mantle tractions needed to rift continents ${ }^{16,62}$. Examples of this association include the separation of North America and Africa that accelerated at the time of the eruption of Central Atlantic magmatic province ${ }^{63} \sim 201$ million years ago (Ma), the break-up of South America and Africa associated with the Paraná and Etendeka flood basalts ${ }^{64}$ that erupted $\sim 133 \mathrm{Ma}$; as well as the breakup of North America and Eurasia and the opening of the North Atlantic ${ }^{65}$ 
associated with the Brito-Arctic Province between 61 and $56 \mathrm{Ma}$. We note that mantle plumes can aid continental rifting, but that they are not a requirement, as shown by, for example, the break-up of Iberia-Newfoundland and Australia-East Antarctica, that proceeded without flood basalt eruptions.
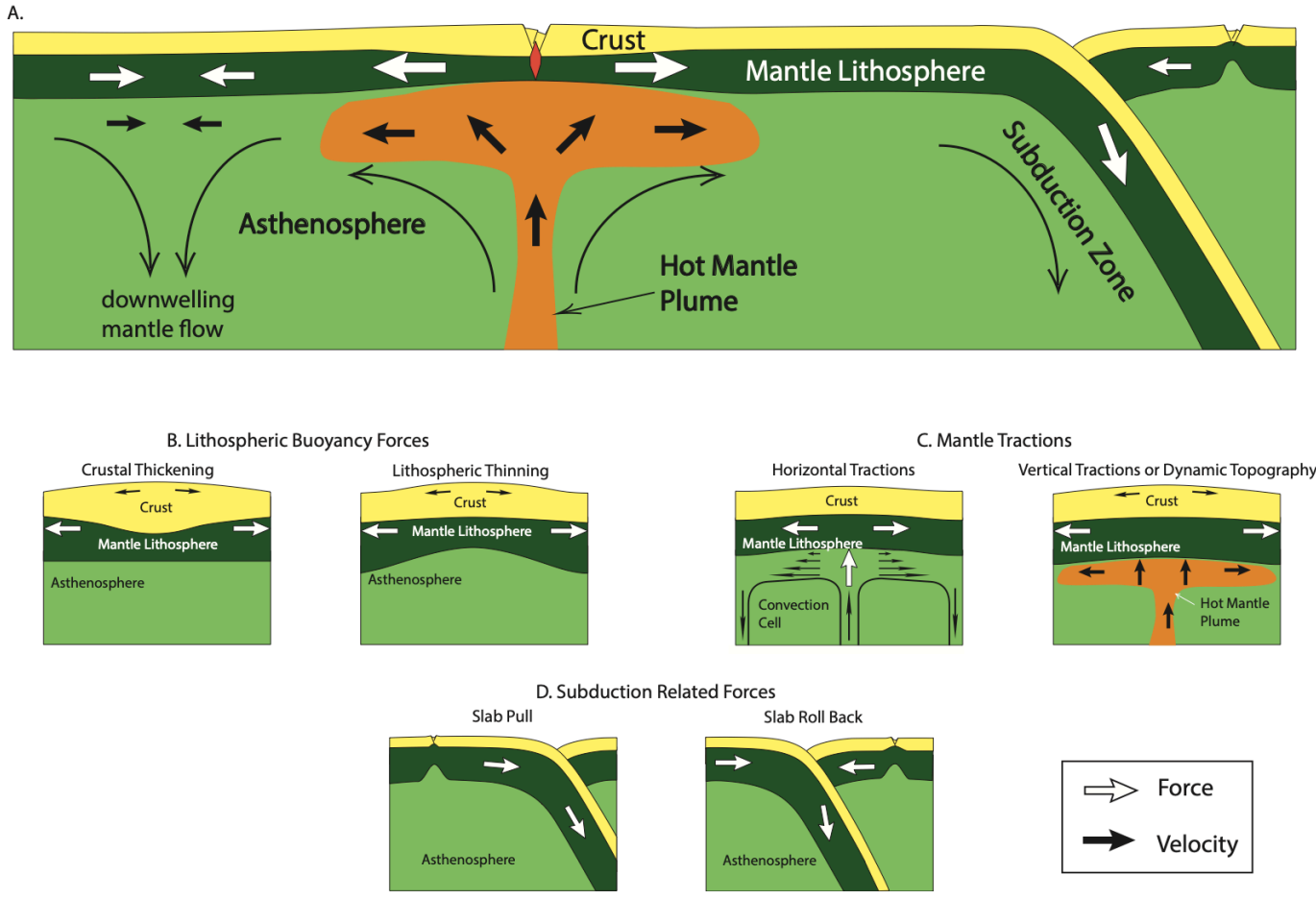

Fig. 2 | Drivers of extension. Simplified representation of major processes and forces that contribute to tensional stresses in the lithosphere. Panel A gives an overview that indicates how stresses of different sources may superpose in one setting. Panels $B-D$ illustrate the individual key drivers of rifting.

\subsection{Subduction-related forces}

Forces related to the subduction (Fig. 2A) of dense lithospheric plates into the sub-lithospheric mantle can potentially add significant far-field stresses that drive rifting. The pull of subduction zones on the attached plates ("slab-pull") is likely to be significant since Earth's subducting plates move 3 to 4 times faster than plates without attached subducting slabs ${ }^{66}$. During "slab rollback", where a subducting slab migrates in the direction opposite to its overall plate motion, the upper plate (that is the plate above the downgoing plate) can be put into extension. "Slab pull" and "slab rollback", like all driving forces, results from gravity acting on lateral variations in density, i.e. GPE gradients, whereas resisting forces are due to the strength of the mantle and crust ${ }^{67}$. The magnitude of the "slab pull" is related to the negative buoyancy of a subducting oceanic plate and can be on the order of several tens of TN/m (Ref. ${ }^{68}$ ). However, since mantle viscosity is thought to increase below the asthenosphere, the dynamic resistance to the downward motion of the plate may be nearly as large as the slab pull force ${ }^{69}$. The sum of these effects may put the trailing part of the down-going plate into extension.

An example of a place where ongoing rifting may be driven by "slab pull" is the Woodlark Basin region of Papua New Guinea. There, the initiation of a new subduction zone located a few hundred kilometres to the north is roughly synchronous with the $10 \mathrm{Ma}$ initiation of Woodlark rifting ${ }^{70,71}$. Another example where subduction may facilitate rifting is the AfroArabian Rift system. As noted above, the East African part of the broader Afro-Arabian Rift system seems not to be directly affected by subduction, but the Red Sea is. The African continent is separating from Arabia across the Red Sea while the Arabian Plate subducts 
beneath the Eurasian Plate. The Red Sea is rifting about an order of magnitude faster than the rest of East Africa ${ }^{72}$ and this may relate to the pull of the subducting plate.

In these two examples, the rift is adjacent to a plate that is being subducted. Subduction can also affect rifts on the upper plate. In places of "slab rollback", a back arc rift can form. Many marginal basins around the Pacific such as the Japan Sea are products of such back-arc rifting $^{73,74}$.

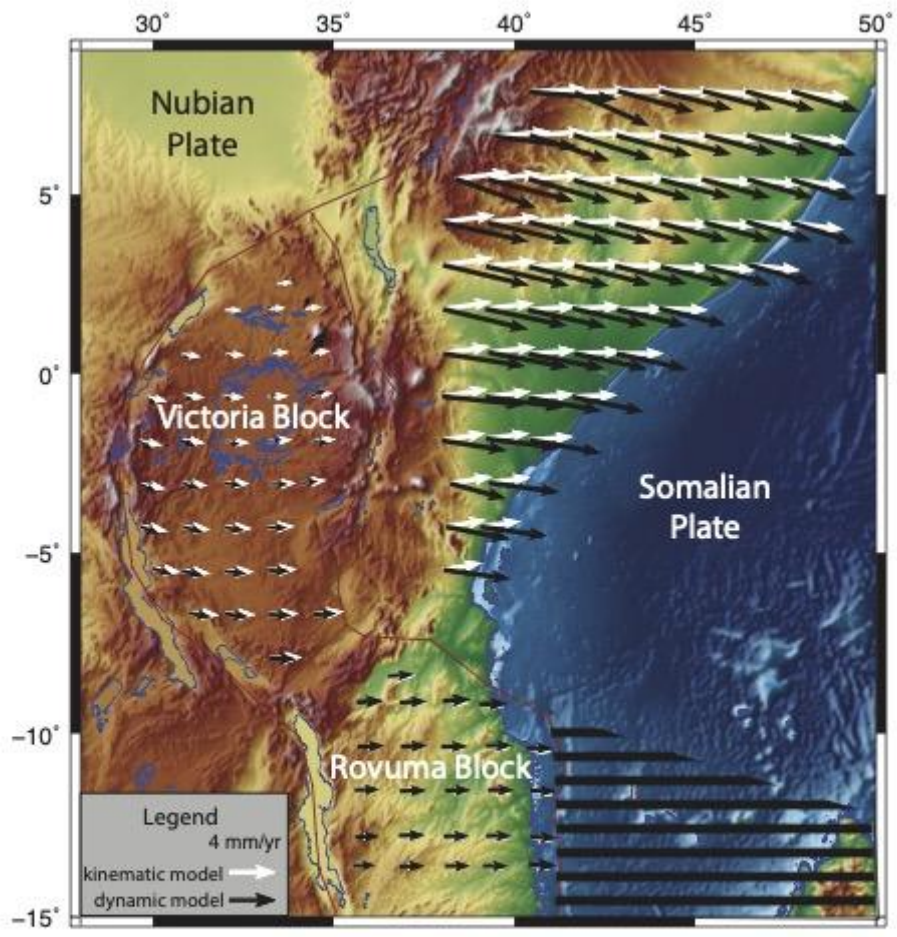

Fig. 3 | East African kinematics. A dynamic model of the East African Rift ${ }^{45}$ that predicts rigid plate motion and East-West extension from lithospheric buoyancy forces as black vectors. White vectors represent rigid plate motions derived from the geodetically constrained kinematic model $^{26}$. The comparison illustrates that lithospheric buoyancy forces are a key factor in driving continental rifting in East Africa.

\section{Resisting factors}

Breaking the strong continental lithosphere requires overcoming a large resistance. In stable interiors of tectonic plates, resisting factors are larger than the drivers of deformation, which is why tectonic motion is focussed along weak plate boundaries. Continental rifts, however, can be considered as nascent plate boundaries where resisting resistance plays an equally important role as the driving forces. In the following, we discuss resisting factors in terms of static strength, inherited weakness, and dynamically resisting forces which arise as a natural consequence of extension.

\subsection{Static resisting factors}

Forming a rift requires bringing the entire continental lithosphere to its yield [G] point, which at low temperatures involves breaking new fractures and faults, and at higher temperatures requires the activation of ductile creep processes ${ }^{75}$. At the lithosphere scale, this can be conceptualised as applying a driving force that matches or exceeds the strength [G] of the plate. The strength is primarily a function of brittle crustal thickness and crustal temperature, but also of overall lithosphere thickness and is determined by brittle and ductile deformation. 

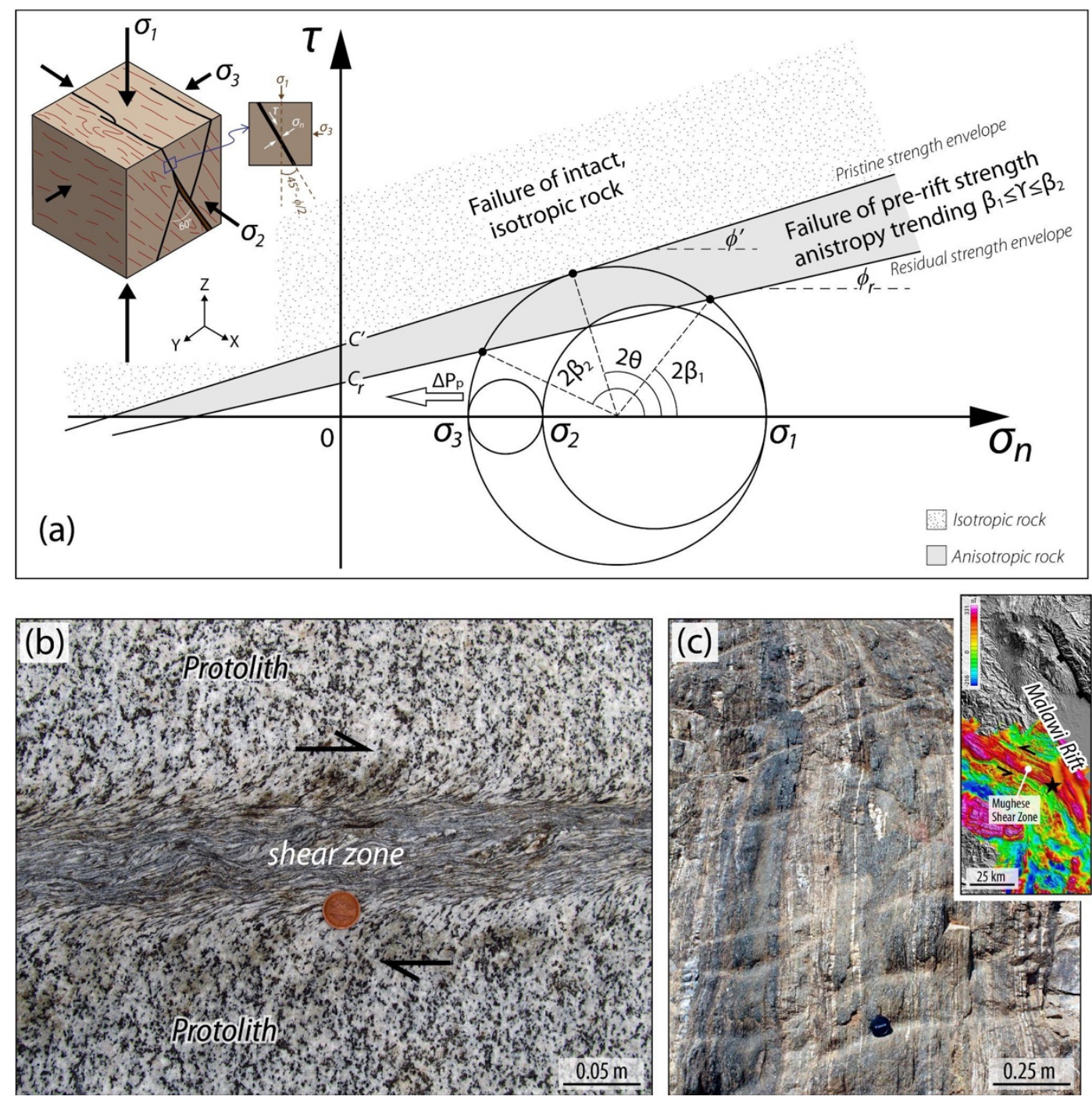

Fig. 4 | Rheological weakening and inheritance. Strength heterogeneities affect rift evolution at all stages and scales. (a) Mohr circles showing the mechanical conditions for the formation of faults or the reactivation and exploitation of inherited (pre-rift) planes of weakness (modified after Ref. ${ }^{86-88}$ ). The friction angle $(\phi)$ and cohesive strength $(C)$ are shown for formation of new planes of failure in intact isotropic rocks ( $\left.\phi^{\prime}, C^{\prime}\right)$ and for reactivation/exploitation of existing ones $\left(\phi_{r}, C_{r}\right)$. The range of orientations for failure of preexisting planes of weakness is broader $\left(\beta_{1} \leq Y \leq \beta_{2}\right)$ than in intact isotropic rock where $\theta$ is the most optimal orientation for brittle failure. The diagram also highlights the role of fluid pressure $\left(\Delta P_{p}\right)$ on the failure of rocks. (b) A small shear zone in a metagranite protolith, Neves Glacier, Italy (photo by Samuele Papeschi). (c) Sheared metadioritic gneisses along the $\sim 15 \mathrm{~km}$-wide Precambrian Mughese Shear Zone (from Ref. ${ }^{89}$ ). Inset: Regional aeromagnetic and hillshade topographic maps showing the extent of the Mughese Shear Zone and location of the photograph (black star). The southern extension of the shear zone has been exploited by normal faults of the Malawi Rift.

At shallow levels ( $15 \mathrm{~km}$ and above), but potentially also in the uppermost portion of the lithospheric mantle, normal faults break when applied stresses reach a frictional threshold that increases linearly with ambient pressure ${ }^{76}$. Faults damage the lithosphere in a highly nonlinear way and localise strain over characteristic widths ranging from tens of micrometres to tens of metres ${ }^{77}$. Brittle failure of crustal rocks is well described by the theory of Mohr-Coulomb elasto-plasticity. This model involves an angle of internal friction $\phi-$ which represents the pressure dependence of rock strength-- and rock cohesion $C$ (Fig. 4). It predicts that faults 
optimally form at an angle of $45^{\circ}-\phi / 2$ to the most compressive stress $\sigma_{1}$ (Ref. ${ }^{76}$ ), which in rift contexts, amounts to dips near $60^{\circ}$ assuming most rocks have an angle of friction near $30^{\circ}$ (Ref. ${ }^{78,79}$ ). Other structural orientations dipping less than $45^{\circ}$ from $\sigma_{1}$ may also be mechanically admissible as a result of fault zone dilatancy ${ }^{80,81}$.

By contrast, ductile viscous-like deformation dominates in hot domains such as the lower continental crust ${ }^{82}$ or the lower portion of the lithospheric mantle ${ }^{83}$ and is characterised by rock strength decreasing non-linearly with temperature. Focussed viscous deformation occurs due to the formation of ductile shear zones at large depths. The width of these shear zones can range from millimetres to tens of kilometres ${ }^{84}$. Ductile deformation within the deep lithosphere is predominantly accommodated by two creep processes acting at the grain scale ${ }^{84,85:}$ (1) diffusion creep where atoms diffuse along grain boundaries and through the crystal lattice, and (2) dislocation creep where imperfections of the crystalline lattice structure migrate. Diffusion creep strain rates increase proportionally to stress, which manifests macroscopically as grain size-sensitive, Newtonian [G] viscous flow. For dislocation creep, however, that relationship is nonlinear and leads to non-Newtonian effective viscosities. Although grain sizeinsensitive, dislocation creep can drive a reduction in grain size that promotes localisation of deformation generating ductile shear zones (Fig. 4b,c).

To understand the force balance in rifts and how it affects tectonic evolution, we need to estimate the total strength of the lithosphere by considering both brittle and ductile deformation mechanisms. For simplicity, we only account for the dominant process - the one that requires less stress (Fig. 5a). For given lithospheric pressure and temperature profiles as well as by assuming typical friction angles and ductile rheologies, a vertical yield stress profile can be approximated. The total strength of the lithosphere corresponds to the surface beneath this yield strength envelope. Some active rifts, such as in the Balangida segment of Northern Tanzania or beneath Lake Tanganyika, feature high rift strength ${ }^{90}$. Here, brittle deformation appears to be dominant in the entire crust and perhaps even in the uppermost mantle as evidenced by the occurrence of deep earthquakes. The efficient localisation of normal faults results in strongly coupled deformation of the crust and mantle, which ultimately leads to the growth of a narrow rift ${ }^{18}$. In the Basin and Range area, however, with little rift strength and predominantly ductile deformation, crust and mantle are decoupled by a low-viscosity lower crust $^{91}$. Here deformation occurs in a distributed, wide rift mode ${ }^{18}$.

\subsection{Structural inheritance}

Suture zones, remnants from previous plate collision events, often constitute a zone of weakness that may get reactivated [G] during eventual extensional deformation. Such pre-rift strength anisotropy in the crust is multi-scale, and can include faults, dike contacts, shear zones, foliation, bedding, joints, lamination, cleavage, and mineralized veins, commonly referred to as basement fabrics. The fact that rifts preferentially develop in previously deformed lithosphere is now well documented across many Wilson cycles ${ }^{92,93}$ [G]. Inherited structures severely modify the static lithospheric strength at the inception of rifting (Fig. 5a) and thereby affect the geometry of the nascent rift on multiple scales.

To first order, deformation of the pre-rift lithosphere is typically associated with previous compressional orogenic events, and is compartmentalised into discrete basement terranes $^{86,93}$ (Fig. 6a). Different structural and thermal evolutions of basement terranes may impose a large-scale mechanical contrast in the bulk rheology and yield strength between terranes, which may allow rifts to preferentially nucleate in a terrane ${ }^{94}$. For example, the Walker Lane trans-tensional rift belt selectively nucleated within the Sierra Nevada Ancestral Cascades, propagated northward along the terrane and has begun to exploit the collinear present-day Cascades Arc terrane ${ }^{95}$. The concept of inherited weakness also explains the common localization of continental rifts within orogenic belts; examples of which include the large-scale localization of the East African Rift System in the orogenic belts that bound the Tanzania Craton ${ }^{86}$, the Central and West African Rift Systems in the Trans-Saharan Mobile Belt and metacratonized lithosphere, the South Atlantic Rift System along the Rio Pardo-West 
Congo Belt ${ }^{96}$, the Mid-Continent Rift along the orogenic belts that bound the Superior Craton ${ }^{97}$, and the North Sea along the Caledonian and Variscan orogens ${ }^{98}$.

Within upper crustal rocks, structural inheritance affects the formation of fault patterns as it often leads to the reduction of frictional parameters $\left(\phi_{r}\right.$ and $C_{r}$ in Fig. 4a) compared to the bulk rock strength. Hence, favourably-oriented pre-existing planes of strength contrast will fail first and localise deformation prior to the nucleation of discontinuities in the pristine portions of the rock $^{88}$. In a normal faulting stress regime, inherited fabrics are ubiquitously exploited [G] by normal or oblique-normal rift faults ${ }^{99-101}$. The exploitation behaviour can however be very complex, as faults form as a result of 3D anisotropies interacting with the 3D stress field. Field observations show that newly formed fault surfaces may align with the fabrics along-strike and down-dip, while faults may also follow fabrics along-strike, but cut across the fabrics obliquely down-dip ${ }^{89,102,103}$. In the East African Rukwa Rift, where basement shear zones strike obliquely to the regional extension direction (parallel to regional $\sigma_{3}$ ), the low stiffness of the shear zones can also cause a local re-orientation of the principal compressive stresses to facilitate exploitation of the shear zones by normal faulting ${ }^{103,104}$. Structural inheritance affects the multiscale segmentation of rift basins ${ }^{105}$ and therefore plays a vital role both for the long-term evolution of a rift and its short-term seismicity.

\subsection{Dynamic resisting processes}

Prolonged lithosphere stretching at a rift generates forces that dynamically interact with the drivers of extension. This interaction takes the form of negative or positive feed-back loops, which we represent here in terms of dynamic resisting (Fig. 5b-d) or dynamic weakening processes (Fig. 5e-g, Sec. 4), respectively.

A major resisting process is isostatic adjustment (Fig. 5b), where crustal thinning generates pronounced surface depressions. Within a mature rift basin with a deep valley, gravitational forces acting at the rift flanks put the rift centre into relative compression. While this force component is usually smaller than the extensional force, it nevertheless opposes continued rifting, which may occasionally lead to inversion events within extensional basins ${ }^{106}$. Flexural isostasy and rift shoulder uplift (Fig. 5c) dynamically change the stress field in the vicinity of a normal fault. This happens in a way that more stress is required to maintain fault activity ${ }^{107-}$ ${ }^{109}$, which ultimately impedes continued deformation.

Lithospheric cooling takes place through conductive heat loss and leads to strengthening of ductile domains (Fig. 5 d), due to their temperature-dependent rheology ${ }^{110}$. Conduction of heat outpaces heat advection in slow rifts ${ }^{111}$, which means that slowly extending lithosphere, where thinning crust is replaced with rheologically stronger mantle rocks, is exposed to a gradual increase of rift strength. Due to cooling, the increasing strength of the rift may eventually exceed the available driving force so that deformation ceases. In this case, the extensional area becomes a so-called failed rift that continues to increase its strength as it cools and subsides. If however the tectonic setting changes, for instance by an increase in tensional forcing, failed rifts may get reactivated. One such example is the Norwegian-Greenland rift, which ceased in the Early Cretaceous after the prominent Møre and Vøring basins off midNorway were formed ${ }^{112}$. Eventually, extension reactivated in latest Cretaceous-Paleocene times adjacent to the original basin that had cooled and strengthened in the meantime ${ }^{113}$. Another example is the northern Kenya Rift, where thermochronological data suggest extensional activity in early Cenozoic times ${ }^{31,114}$ (60-50 Ma). This phase of rifting however ceased leading to a seemingly failed rift until the latest phase of extension initiated in middle Miocene times (ca. $15 \mathrm{Ma}$ ). 
(a) Yield strength envelopes

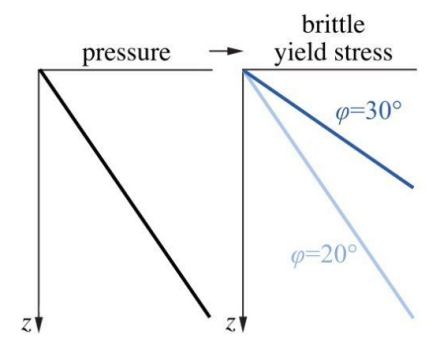

Dynamic resistance

(b) Local isostasy

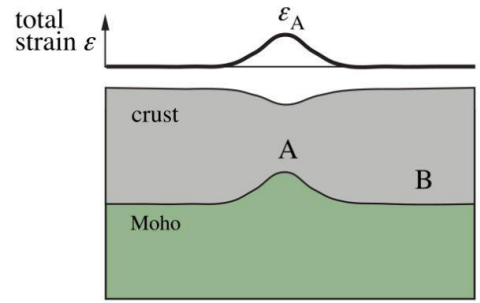

(c) Regional isostasy

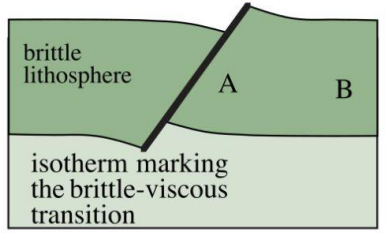

(d) Thermal diffusion

\begin{tabular}{|l|}
\hline $\begin{array}{l}\text { brittle } \\
\text { lithosphere }\end{array}$ \\
\hline
\end{tabular}
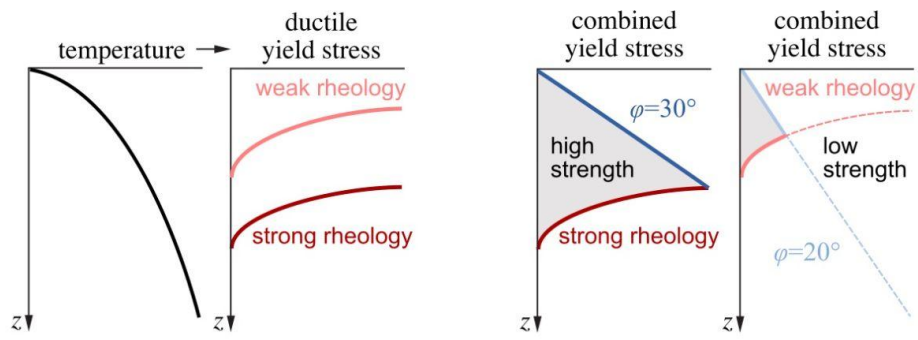

Dynamic weakening

(e) Necking, thermal advection, intrusion-related heating
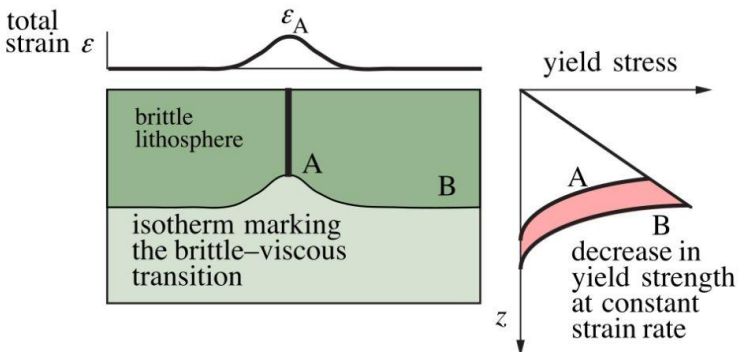

(f) Magmatic intrusion stress
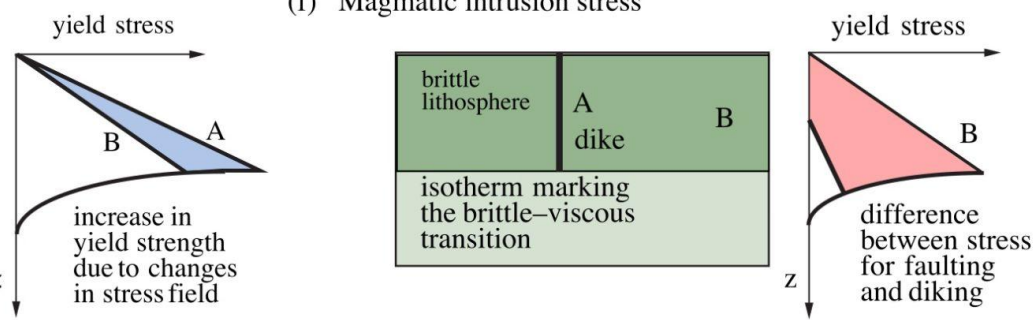

(g) Fault weakening

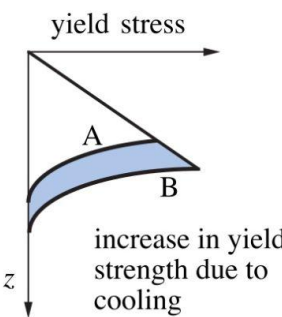

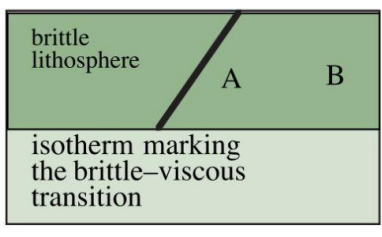

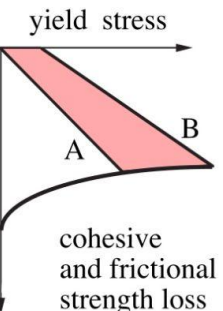

Fig. 5 | Lithospheric strength and response to deformation. Strength envelopes illustrate the conceptual strength distribution within the lithosphere and allow for estimating the firstorder impact of geodynamic processes on rifting. (a) Simplified representation of lithospheric yield strength envelopes. (b-d) Dynamic processes impeding deformation. (e-g) Dynamic processes facilitating deformation. The relative magnitude of resisting and weakening processes as well as their interaction with driving forces is site and time-dependent. Panels $b-g$ are modified from Ref. ${ }^{40}$. 


\section{Weakening processes}

Extending continental lithosphere is accompanied by a range of weakening processes. These processes involve weakening associated with strain localisation, such as, grain-size reduction in mylonitic shear zones, gouge formation in crustal faults, and lithospheric necking, as well as dike-related magmatic weakening, and surface processes. It is the dynamic interaction between these processes that generates the complex surface expressions during rift evolution.

\subsection{Strain localization}

The axes of continental rifts are delineated by a population of normal faults whose lengths and offsets typically follow exponential or heavy-tailed distributions ${ }^{115-117}$. This means that while small faults are extremely pervasive, slip on one or two crustal scale "master" faults dominates the creation of relief ${ }^{118,119}$, i.e., a sedimentary basin on the hanging wall side (e.g., major lakes in the East African Rift, the Gulf of Corinth) and a mountain range on the footwall side (e.g., the Teton range in Wyoming). In some instances, prolonged slip on a major normal fault inevitably prompts the initiation of a new master fault in its vicinity, because prolonged warping of fault-bounded blocks drives them to failure ${ }^{107,108}$. This enables rapid shifts in the location of rift axes ${ }^{120}$, which can culminate in the development of wide rifts such as the Basin and Range Province, where no clear axis can be defined ${ }^{18}$. On the other hand, the accumulation of slip on a master fault can be a stable process: a necessary condition for the formation of narrow rifts as well as core complexes [G] bounded by very-large offset $(10+\mathrm{km})$ detachment faults ${ }^{18,121}$. These structures are examples of extreme strain localization in the brittle upper crust, possibly accompanied by localised viscous fault roots or mylonitic shear zones in the lower crust and mantle ${ }^{122}$. In the field, they manifest as topographic domes capped by low-angle fault surfaces that expose deep structural levels, e.g., the Whipple Mountains in the Southwestern United States ${ }^{123}$.

Once rift faults are established, further fault weakening may occur through a reduction in fault cohesion and/or friction (Fig. $4 \mathrm{~g}$ ), for example due to strain-assisted fluid-rock reactions that precipitate frictionally weak phyllosilicates in fault gouges ${ }^{124-126}$. It should be noted, however, that such weak phases may not be frictionally stable in hotter portions of the brittle upper crust (e.g., beyond $\sim 200^{\circ} \mathrm{C}$ for some clay minerals). Elevated pore fluid pressures may also reduce the differential stress [G] required for slip on faults by decreasing their effective normal stress $^{127-129}$ (Fig. 4a). While this effect is often invoked as a weakening mechanism in compressional settings ${ }^{127,130}$, elevated fluid pressures in a rifting context can easily lead to net tensile stresses, which would drive hydro-fracturing and lower pore pressures down to a hydrostatic state ${ }^{125,131}$. Finally, frictional softening during rifting can also occur due to serpentinisation [G] of mantle rocks ${ }^{132,133}$. This process requires water to be transported from the surface to the top of the mantle via active faults cutting through the entire crust. Serpentinisation-induced weakening has been particularly well documented at the West Iberian rifted margin ${ }^{134,135}$ and is thought to occur only during the late stages of rifting when the crust is sufficiently cool to become entirely brittle ${ }^{136,137}$.

Beyond fault weakening, fluid flow also plays a vital role in the formation of georesources. The extensional stress field within rift fault networks provides ideal conditions for enhanced permeability and widespread fluid circulation at depth ${ }^{138,139}$. The elevated heat flow in rift systems can therefore be efficiently exploited for geothermal energy production, which is already done for instance in the Basin and Range ${ }^{140}$, the Kenya Rift ${ }^{141}$, and the Rhine Graben ${ }^{142}$ but large exploration potentials exist in other rifts as well ${ }^{1}$. Furthermore, fluid flow along rift faults constitutes a pathway to release deeply sourced carbon dioxide ${ }^{10,143}$, which may affect long-term climate evolution ${ }^{144}$ and can additionally reduce the strength of normal faults ${ }^{129,145}$.

In numerical models of rift evolution, a rapid drop in effective strength with accumulated strain enables faults to stay active under low differential stresses (Fig. 6), and flexurally rotate to 
dips less favourable than $60^{\circ}$ as the faulted blocks deform ${ }^{109,146-149}$. In models where the brittle upper crust overlies a weak, nearly inviscid lower crust, cohesion loss appears sufficient to sustain slip on an infinitely long-lived fault ${ }^{109,150}$. This is not the case in models that account for a strong lower crust or mantle where viscous flow exerts a defocusing effect on brittle deformation ${ }^{151}$. In this class of models, friction weakening appears necessary to keep brittle deformation localised ${ }^{19,133,152}$.

Weakening mechanisms have also been proposed to facilitate strain localization at ductile levels ${ }^{84,153}$. High-temperature, non-Newtonian ductile creep processes may aid strain localization by reducing the rock's effective viscosity as its deformation rate increases. High strain rates may also reduce grain size, making rocks effectively weaker when deforming in the diffusion creep regime ${ }^{154,155}$. In numerical simulations, the development of a localised, lowviscosity channel in the lower crust enables the position of localised strain in the upper crust to migrate laterally over hundreds of $\mathrm{km}$, resulting in the formation of asymmetric (wide and narrow) conjugate margins at the late stages of rifting ${ }^{20,156}$.

At lithospheric scales, brittle and ductile weakening lead to successive focussing of extensional strain within the rift (Box 1). Accumulated thinning or so-called necking of the lithosphere constitutes a large-scale thermal weakening process that replaces cold and strong lithosphere with hot and weak asthenosphere ${ }^{157}$. Numerical models have assessed the relative impact of strain softening versus lithospheric thinning and found that necking dominates the loss of lithospheric strength due to the highly non-linear dependence of rock viscosity on temperature ${ }^{158}$. The prominent reduction in lithospheric strength during rift evolution may even generate a feed-back on plate kinematics such that the loss of rift strength induces an acceleration of the involved plates ${ }^{159,160}$. This process may explain the speed-up of North America during Central Atlantic rifting ${ }^{161}$, of South America during rifting of the South Atlantic $^{15}$, and of Australia during its separation from Antarctica ${ }^{162}$.

\subsection{Surface processes}

The creation of topography is an integral part of localised deformation at continental rifts. Crustal thinning and slip on crustal-scale faults result in basin subsidence and rift shoulder uplift through flexural isostasy ${ }^{118}$. Such relief is continuously reworked by surface processes, with fluvio-glacial erosion, gravitational mass wasting and hillslope diffusion acting to level positive topography while transport and deposition of the resulting sediment blankets and fills subsiding areas ${ }^{163}$. Such redistribution of surficial masses impacts the stress and thermal state of the crust in a manner that can influence its tectonic evolution.

Numerical models where long-term tectonic simulations are coupled with landscape evolution models have played a prominent role in investigating feedbacks between tectonics and surface processes. Early models in the 1990s focused on the plate boundary scale and relied on diffusive parameterizations of surface processes ${ }^{164,165}$ to show that topographic redistribution could influence lower crustal flow by altering lateral pressure gradients. Sedimentation facilitates this process by warming the geotherm through "thermal blanketing", thereby reducing the effective viscosity of the lower crust. In a mechanical sense however, sedimentation alleviates the dynamic resistance that develops through isostatic thinning of the continental crust ${ }^{166}$ (Fig. 5b,c). In this framework, sedimentation favours the narrow rifting mode, which for example characterises deformation in the highly sedimented Gulf of California.

As models became able to resolve individual fault zones, additional feedbacks were recognized between surface processes and brittle strain localization. Efficient surface processes can alleviate a portion of the energy required to warp faulted blocks and grow relief $^{167}$. This process delays shifts in strain localization, particularly in weak crust ${ }^{168,169}$. Erosion and sedimentation thus result in longer-lived half-graben master faults which accommodate larger offsets prior to being abandoned. This phenomenon was also recognized in subsequent rift-scale simulations, which showed that enhanced brittle strain localization 
combined with sedimentation-induced reduction in lower crustal viscosity could accelerate the timing of continental breakup compared to a setup with inefficient surface processes ${ }^{170,171}$. Surface processes therefore act as an external weakening mechanism that promotes strain localisation both for individual normal faults and at the plate boundary scale.

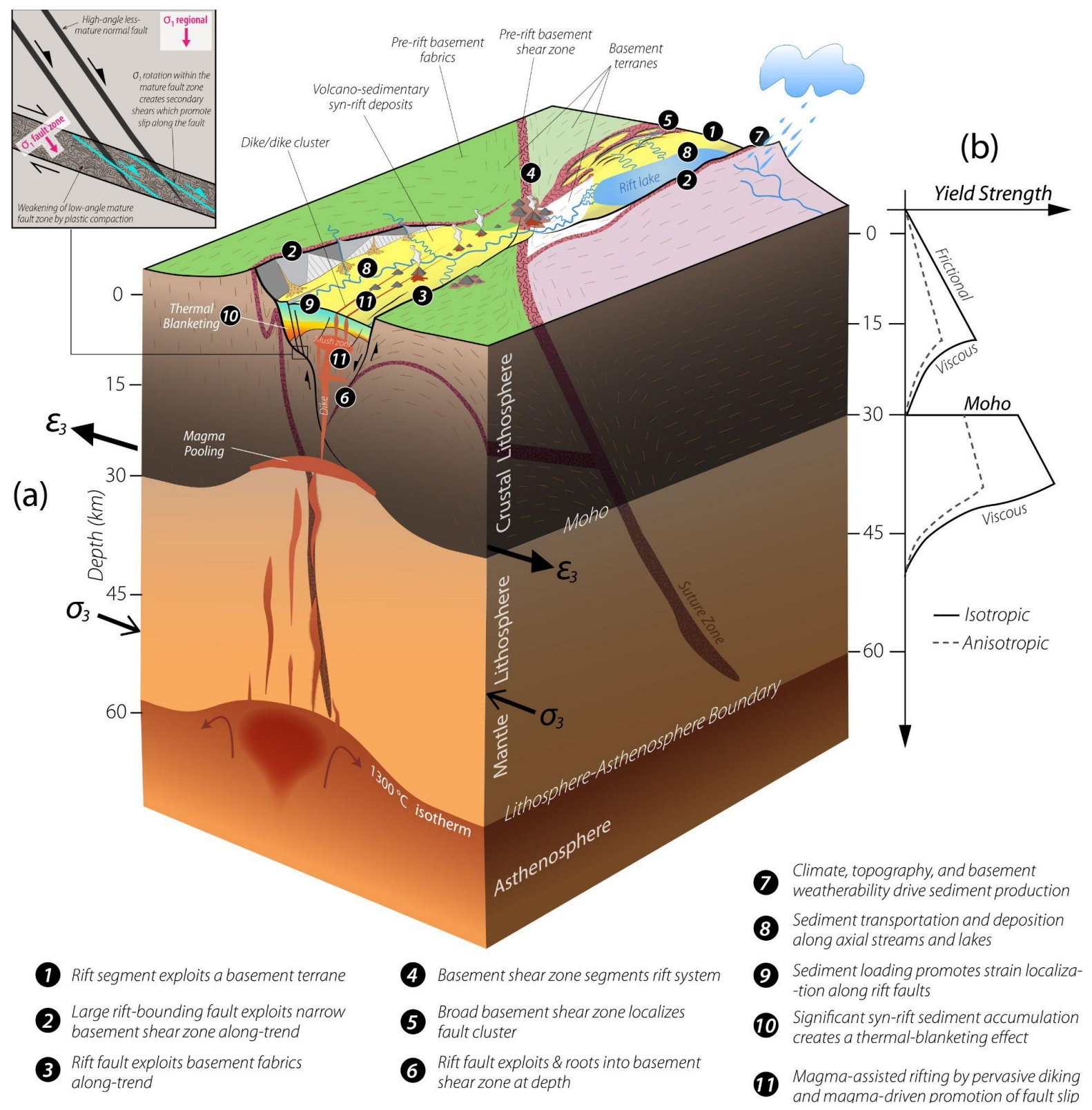

Fig. 6 | Weakening processes in a continental rift. A wide range of rheological, thermal, and mechanical softening processes enable strain localization at lithospheric, crustal, and fault zone scales. (a) Simplified 3-dimensional illustration of a continental rift zone, highlighting the various weakening structures and processes. The arrows on the side of the 3D block represent the regional minimum compressive principal stress (regional $\sigma_{3}$ ) and the regional maximum horizontal extension (regional $\varepsilon_{3}$ ) directions. (b) Strength profile of the crust and lithosphere, showing the relatively lower yield strength imposed by the presence of mechanical anisotropy. 


\subsection{Magmatic weakening}

The generation of magma within the asthenosphere and deep lithosphere of continental rifts can be caused by two processes. On the one hand, decompression melting can be induced by the adiabatic ascent of mantle rocks due to the thinning of continental lithosphere, with the production of higher melt volumes at greater stretching factors ${ }^{172}$. On the other hand, melts can also be generated due to elevated mantle potential temperatures that may either be induced by the impingement of mantle plumes on the lithosphere ${ }^{17}$, by broad asthenospheric upwelling associated with lithospheric thinning ${ }^{173,174}$ (Fig. 6), or by small-scale convection at lithospheric edges ${ }^{175,176}$. Melting can be further enhanced by the presence of fusible metasomes in the lithospheric mantle ${ }^{177}$.

Buoyant melts are thought to ascend by porous flow faster than the mantle upwells, and to accumulate beneath permeability barriers, which in the mantle may closely align with the $1240^{\circ} \mathrm{C}$ isotherm ${ }^{178}$. This focuses melt towards the region of lithospheric necking, and possibly produces a decompaction boundary layer ${ }^{179}$ at the lithosphere-asthenosphere boundary. Modes of melt transport through the lithosphere are still poorly understood, but likely involve the propagation of magma-filled fractures from pressurised magma pockets ${ }^{180}$ (Fig. 6a). The latent heat associated with repeated dike intrusions near the lithosphere-asthenosphere boundary may drive significant thermal erosion that thins the lithosphere ${ }^{181}$, and weakens it much more rapidly than amagmatic upwelling due to stretching alone. Another key effect of pervasive diking is to drastically alleviate the force needed to drive rifting. Because basaltic magmas typically produced at rifts are slightly less dense than the continental crust, opening a dike with magma-static pressure across the brittle crust requires much less force than breaking normal faults (Fig. 5f). Such processes are thought to have controlled the development of the Red Sea and Ethiopian rift, and may play a role in keeping the axes of these rifts remarkably straight ${ }^{62,182}$. In addition, regional changes in stress state due to volume changes within mid-crustal magmatic mush zones during large intra-rift caldera eruptions, appear to temporally promote slip on the rift faults within their vicinity ${ }^{183}$ (Fig. 6a).

\section{Force balance and rift evolution}

The timing and location of rift initiation can be understood when considering the interplay between the geodynamic drivers of extension and the mechanical resistance of the continental lithosphere. In most continental areas, tectonic driving forces are smaller than lithospheric strength, generating continental interiors that remain stable over hundreds of million years. However, a critical change in the geodynamic environment can lead to an increase of the driving forces or to a decrease of the resisting strength so that the force balance eventually tips and tectonic activity commences. Such a tipping point might be generated by the impingement of a mantle plume ${ }^{17}$ beneath the lithosphere, whereby the topographic deflection due to the plume's buoyancy increases the tensional force, while elevated mantle temperatures generate melts that weaken the lithosphere. A prominent example of plume-rift interaction is East Africa ${ }^{184}$. Another reason can be a change in the plate boundary configuration such as the transition from subduction to continental collision that alters the continental stress field in a critical way. For instance, the collision of the Adriatic plate with Eurasia that is responsible for the formation of the European Alps also induced the tensional stress regime that generated the Rhine Graben and the Eger Rift in Central Europe $^{185}$.

Whether or not a rift system evolves to break-up is controlled by the non-linear feedbacks between weakening and strengthening processes. One key variable in this interplay is rift velocity: fast rifting such as in the Gulf of Corinth ${ }^{186}$ with $\sim 15 \mathrm{~mm} / \mathrm{yr}$ or the Woodlark Rift ${ }^{187}$ with up to $30 \mathrm{~mm} / \mathrm{yr}$ leads to fast heat advection that can not be counteracted by conductive cooling ${ }^{111}$. High temperatures within the rift lead to rheological weakening and enhance partial melting, both of which decrease rift strength and thus enhance tectonic activity. In contrast, 
slow rifts like the Rhine Graben ${ }^{188}$ or the Rio Grande Rift ${ }^{189}$ with only $\sim 1 \mathrm{~mm} / \mathrm{yr}$ divergence velocity will likely evolve into failed rifts eventually.

The balance between tectonic driving forces and lithospheric strength is different for each rift and often difficult to quantify, particularly for past rifting phases. But since the dynamic feedback relationships between all involved factors are the same for all rifts, we can nevertheless deduce some overarching rules for the evolution of rifts in general. One such rule is that rifts, which experience plume impingement always become successful and ultimately form ocean basins ${ }^{93}$. This effect results from the simultaneous plume-induced increase of driving force and decrease of rift strength. Another general rule is that successful continent-scale rifts feature a prominent abrupt acceleration once the lithosphere is sufficiently weakened $^{159}$. This behaviour marks the transition from a state where the extension velocity is limited by rift strength to a state where the velocity is controlled by the plate-scale force budget. Concerning failed rifts we infer that lithospheric weaknesses can be inherited over hundred millions of years so that failed rifts actually constitute dormant rifts that eventually reactivate once the tensional driving forces become sufficiently large.

\section{Summary and future directions}

In this review we apply a geodynamic perspective to investigating controls on rift localization and evolution. We view continental rifts as a product of driving and resisting forces, modified by both weakening and strengthening processes, that ultimately lead to rift success (the plate breaks) or failure (the rift is abandoned). Two immediate conclusions can be drawn from this perspective: First, that continental rifting is not a steady-state process, but instead rifts evolve non-linearly in phases that can overprint each other as their force equilibrium shifts, and second that rift evolution is a spatial and temporal scale-dependent competition between the driving and resisting forces and their modifiers.

Continental rifts evolve where and when lithospheric strength is overcome. Lithospheric strength varies across continents and over time as a function of crustal and lithospheric thickness, lithology, and the state variables velocity, temperature, and pressure. A geodynamic understanding of rift evolution thus requires evaluation of these strength controls as well as a careful choice of how strength is quantified and compared ${ }^{110,113}$. We should keep in mind that strength minima on a regional scale are not necessarily strength minima on a plate scale. This implies that rift systems may 'try out' different strength minima simultaneously, until one system takes over and the other becomes dormant. The North Atlantic rift system, for example, was not only active in the North Atlantic Ocean ${ }^{190}$ (break-up ca. $54 \mathrm{Ma}$, still active), but also in the Labrador Sea ${ }^{191}$ (seafloor-spreading ca. 65 to $35 \mathrm{Ma}$, now inactive) and the North Sea ${ }^{192}$ (failed). The Eastern and Western branches of the East African Rift System are currently still competing as to which branch will focus stress to the stage of continental break-up. Even though we have made progress in understanding how the interaction of evolving driving and resisting forces controls rifting, the ultimate recipe of rift success, or rift failure, is not yet written.

Rift abandonment can occur prior to break-up, but also after, as illustrated by the Atlantic rifts west and east of Greenland and the jump from spreading west of the Jan Mayen microcontinent (offshore East Greenland) to east. We argue that the causes of rift abandonment are to be found in the force balance of the region, and thus its lithospheric strength evolution, but the question of the spatial and temporal scales at which this balance should be addressed is still open. We encourage future studies to search for tipping points in the force balance by studying not only the successful systems, but also the systems that failed. This requires a close integration of quantitative modelling techniques with observational approaches.

Observational constraints on rift controls will help unravel the evolution of lithospheric strength during rifting and break-up through quantifications of crustal and lithospheric thickness, 
thermal state, and topography. This can include thermochronological dating of fault surfaces and river networks to reveal vertical motion changes ${ }^{193,194}$, joint inversion of seismic, tomographic and satellite data to reveal lithosphere structure ${ }^{195}$, and inversion for lithospheric rheology and temperature structure from topography, gravity, horizontal and vertical surface velocities $^{196}$.

As numerical techniques and access to computational power improve, dynamic rift studies increasingly address rifting in 3D. We have found that most rift systems develop with oblique kinematics rather than purely orthogonal ${ }^{197}$, but questions remain as to how strain is partitioned in oblique systems, how the 3D character of shear zone coalescence ${ }^{198}$ controls along-strike structural and thermal differences, and how rifts propagate laterally and alongstrike. In addition to increasingly higher numerical resolution, recent technical improvements, such as the mesh-insensitive implementation of shear zones ${ }^{199}$ and the integration of lithospheric with mantle dynamics ${ }^{160}$, allow more detailed comparisons of numerical with observation statistical datasets. New insights may also be expected from close comparisons with analogue models, as this technique is becoming increasingly more quantitative, with new approaches examining scissor-opening and rotational dynamics ${ }^{200}$ of rifts as well as the influence of including an asthenosphere ${ }^{201}$.

A geodynamic perspective of the force balance involved in rift initiation and rift evolution will help understand how supercontinents, as Pangea, can break apart, ultimately feeding back into quantitative constraints on plate tectonic reconstructions. Identifying the controls on lithospheric strength, and their temporal weakening or strengthening processes, will improve our understanding of crustal and lithospheric stress build-up that determines seismic hazard in rift regions. Advancing monitoring techniques of fault-related volatile release are required to quantify the connection between fault strength and the subsurface flow of fluids and volatiles, also allowing for more precise estimates of rift-induced carbon dioxide degassing. Finally, a more profound knowledge of the interaction between fault networks, sedimentary processes and fluid flow will lead to better understanding of rift-related geothermal energy systems and the formation of strategic mineral deposits needed for green energy technologies.

\section{Glossary}

Basal shear stress: A stress that is imposed by viscous mantle flow at the base of the lithosphere. It is defined by the vertical gradient of horizontal velocity times the viscosity at the lithosphere-asthenosphere boundary.

Carbon capture and storage: A climate mitigation strategy to reduce effective carbon emissions by long-term storage of carbon in the underground.

Core complex: Exposure of metamorphosed lower crustal rocks that are exhumed to the surface along long-offset normal faults.

Differential stress: The difference between the maximum and minimum principal stresses.

Distal margin: The near-ocean domain of rifted margins. Characterised by thin continental crust, titled continental blocks and regions of exhumed lithospheric mantle.

Driving forces: Plate tectonic driving forces result from gravity acting on lateral variations in density. These variations are caused by the topography of Earth's surface or of internal layers and by thermal or compositional heterogeneities like subducting slabs or mantle plumes.

Exploitation: A process by which extensional brittle rift structures (faults and joints) develop along pre-existing strength anisotropies of a ductile regime that was inherited from an older compressional tectonic event. 
Gravitational potential energy (GPE): The energy of an object owing to its position in a gravitational field. GPE gradients constitute a force that emerges due to lateral topography and density variations.

Line force: Force per plate boundary length with typical units TN/m.

Lithospheric strength: The vertical integral of the maximum differential stress (i.e., the yield stress) between Earth's surface and the lithosphere-asthenosphere boundary. Often described as a line force.

Mantle plume: An upwelling in the mantle characterised by higher temperature and lower density relative to the adjacent mantle. Classically depicted with a columnar tail and a mushroom-shape head. The depth of origin of mantle plumes is debated, with the deepest origin placed at the core-mantle-boundary.

Mantle traction: The force per area exerted by mantle flow along the base of a plate. A vector variable with units of stress (MPa).

Natural hydrogen: Hydrogen that is generated by natural processes such as serpentinization of ultramafic rocks or water radiolysis.

Newtonian rheology: A type of fluid deformation where viscous stresses arising from the flow are linearly correlated to the local strain rate. The viscosity of a Newtonian fluid is therefore constant as a function of strain rate or stress, but typically depends on temperature.

Proximal margin: The near-coastal domains of rifted margins that are thought to record the early phases of extension. Often characterised by sedimentary basins and steep normal faults.

Reactivation: A process by which old brittle structures (faults and joints) that are inherited from older tectonic events (e.g., earlier rift phase) are rejuvenated as extensional rift structures.

Resisting factors: Factors that oppose tectonic deformation. Resistance can be exerted statically or through dynamic processes.

Serpentinisation: Serpentinization is a chemical alteration process of ultramafic rocks where olivine, pyroxene and water react to serpentine minerals under the release of natural hydrogen. This process affects tectonic deformation by decreasing frictional rock strength and increasing its volume.

Weakening processes: Processes that reduce the strength of the lithosphere for instance due to temperature increase, mechanical damage, or increased fluid pressure. Weakening processes are often interlinked by non-linear feedbacks.

Wilson cycle: Represents the concept that the same plate boundaries are involved repeatedly during plate tectonic history, which implies that inherited plate weaknesses persist over geological times.

Yield: The maximum differential stress that a material can sustain before it deforms by brittle fracture or ductile flow.

\section{Acknowledgements}

We thank Samuele Papeschi for kindly providing the shear zone image in Fig. 4b. The work was supported by the North-German Supercomputing Alliance (HLRN).

\section{Author contributions}


All authors contributed to the scientific input, writing and editing of the manuscript. Sascha Brune developed the concept and structure of the manuscript.

\section{Competing interests}

The authors declare no competing interests.

\section{References}

1. Jolie, E. et al. Geological controls on geothermal resources for power generation. Nat. Rev. Earth Environ. 1-16 (2021) doi:10.1038/s43017-021-00154-y.

2. Leach, D. L. et al. Sediment-Hosted Lead-Zinc Deposits in Earth History. Econ. Geol. 105, 593-625 (2010).

3. Wilkinson, J. J. Sediment-Hosted Zinc-Lead Mineralization: Processes and Perspectives: Processes and Perspectives. Treatise Geochem. 2nd Ed. (2013).

4. Hund, K. et al. Minerals for climate action: the mineral intensity of the clean energy transition. World Bank (2020).

5. Snæbjörnsdóttir, S. Ó. et al. Carbon dioxide storage through mineral carbonation. Nat. Rev. Earth Environ. 1, 90-102 (2020).

6. Allen, P. A. \& Allen, J. R. Basin Analysis: Principles and Application to Petroleum Play Assessment. (John Wiley \& Sons, 2013).

7. Lefeuvre, N. et al. Native H2 Exploration in the Western Pyrenean Foothills. Geochem. Geophys. Geosystems 22, e2021GC009917 (2021).

8. Meghraoui, M. et al. Active Normal Faulting in the Upper Rhine Graben and Paleoseismic Identification of the 1356 Basel Earthquake. Science 293, 2070-2073 (2001).

9. Biggs, J. et al. Volcanic activity and hazard in the East African Rift Zone. Nat. Commun. 12, 6881 (2021).

10. Tamburello, G., Pondrelli, S., Chiodini, G. \& Rouwet, D. Global-scale control of extensional tectonics on $\mathrm{CO} 2$ earth degassing. Nat. Commun. 9, 4608 (2018).

11. Dewitte, O. et al. Constraining landslide timing in a data-scarce context: from recent to very old processes in the tropical environment of the North Tanganyika-Kivu Rift region. Landslides 18, 161-177 (2021).

12. Şengör, A. M. C. \& Natal'in, B. A. Rifts of the World. Geol. Soc. Am. Spec. Pap. 352, 389482 (2001).

13. Sapin, F., Ringenbach, J.-C. \& Clerc, C. Rifted margins classification and forcing parameters. Sci. Rep. 11, 8199 (2021).
14. Lundin, E. R. \& Doré, A. G. Hyperextension, serpentinization, and weakening: A new paradigm for rifted margin compressional deformation. Geology 39, 347-350 (2011).

15. Heine, C., Zoethout, J. \& Müller, R. D. Kinematics of the South Atlantic rift. Solid Earth 4, 215-253 (2013).

16. Courtillot, V., Jaupart, C., Manighetti, I., Tapponnier, P. \& Besse, J. On causal links between flood basalts and continental breakup. Earth Planet. Sci. Lett. 166, 177-195 (1999).

17. Koppers, A. A. P. et al. Mantle plumes and their role in Earth processes. Nat. Rev. Earth Environ. 2, 382-401 (2021).

18. Buck, W. R. Modes of Continental Lithospheric Extension. J. Geophys. Res.Solid Earth 96, 20161-20178 (1991).

19. Brune, S., Heine, C., Perez-Gussinye, M. \& Sobolev, S. V. Rift migration explains continental margin asymmetry and crustal hyper-extension. Nat. Commun. 5, (2014).

20. Tetreault, J. L. \& Buiter, S. J. H. The influence of extension rate and crustal rheology on the evolution of passive margins from rifting to break-up. Tectonophysics doi:10.1016/j.tecto.2017.08.029.

(2018)

21. Neuharth, D. et al. Evolution of Rift Systems and Their Fault Networks in Response to Surface Processes. Tectonics 41, e2021TC007166 (2022).

22. Baker, B. H. \& Wohlenberg, J. Structure and Evolution of the Kenya Rift Valley. Nature 229, 538-542 (1971).

23. Stewart, J. H. Basin and Range Structure: A System of Horsts and Grabens Produced by Deep-Seated Extension. Geol. Soc. Am. Bull. 82, 1019-1044 (1971).

24. Allmendinger, R. W. et al. Cenozoic and Mesozoic structure of the eastern Basin and Range province, Utah, from COCORP seismic-reflection data. Geology 11, 532-536 (1983).

25. Brun, J. P. \& Wenzel, F. Crustal-scale structure of the southern Rhinegraben from ECORS-DEKORP seismic reflection data. 
Geology 19, 758-762 (1991).

26. Stamps, D. S., Kreemer, C., Fernandes, R., Rajaonarison, T. A. \& Rambolamanana, G. Redefining East African Rift System kinematics. Geology 49, 150-155 (2021).

27. Owen, R. B. et al. Quaternary history of the Lake Magadi Basin, southern Kenya Rift: Tectonic and climatic controls. Palaeogeogr. Palaeoclimatol. Palaeoecol. 518, 97-118 (2019).

28. McNeill, L. C. et al. High-resolution record reveals climate-driven environmental and sedimentary changes in an active rift. Sci. Rep. 9, 3116 (2019).

29. Gill, R. Igneous Rocks and Processes: $A$ Practical Guide. (John Wiley \& Sons, 2011).

30. Reiners, P. W. et al. Geochronology and Thermochronology. (John Wiley \& Sons, 2017).

31. Torres Acosta, V. et al. Cenozoic extension in the Kenya Rift from low-temperature thermochronology: Links to diachronous spatiotemporal evolution of rifting in East Africa. Tectonics 2015TC003949 (2015) doi:10.1002/2015TC003949.

32. Rooney, T. O. The Cenozoic magmatism of East-Africa: Part I — Flood basalts and pulsed magmatism. Lithos 286, 264-301 (2017).

33. Boone, S. C. et al. Birth of the East African Rift System: Nucleation of magmatism and strain in the Turkana Depression. Geology (2019) doi:10.1130/G46468.1.

34. Merdith, A. S., Williams, S. E., Brune, S., Collins, A. S. \& Müller, R. D. Rift and plate boundary evolution across two supercontinent cycles. Glob. Planet. Change 173, 1-14 (2019).

35. Müller, R. D. et al. A Global Plate Model Including Lithospheric Deformation Along Major Rifts and Orogens Since the Triassic. Tectonics 38, 1884-1907 (2019).

36. McKenzie, D. Some remarks on the development of sedimentary basins. Earth Planet. Sci. Lett. 40, 25-32 (1978).

37. Karner, G. D., Driscoll, N. W., McGinnis, J. P., Brumbaugh, W. D. \& Cameron, N. R. Tectonic significance of syn-rift sediment packages across the Gabon-Cabinda continental margin. Mar. Pet. Geol. 14, 973-1000 (1997).

38. Brun, J.-P., Sokoutis, D. \& Driessche, J. V. D. Analogue modeling of detachment fault systems and core complexes. Geology 22, 319-322 (1994).

39. Corti, G. et al. Analogue modelling of continental extension: a review focused on the relations between the patterns of deformation and the presence of magma. Earth-Sci. Rev.
63, 169-247 (2003).

40. Buck, W. R. The Dynamics of Continental Breakup and Extension. in Treatise on Geophysics, 2nd Edition, Vol 6 - Crust and Lithosphere Dynamics (Elsevier, 2015).

41. Gerya, T. Introduction to numerical geodynamic modelling, 2nd Edition. (Cambridge University Press, 2019).

42. Artyushkov, E. V. Stresses in the Lithosphere Caused by Crustal Thickness Inhomogeneities. J. Geophys. Res. 78, PP. 7675-7708 (1973).

43. Fleitout, L. \& Froidevaux, C. Tectonics and topography for a lithosphere containing density heterogeneities. Tectonics 1, PP. 2156 (1982).

44. Coblentz, D. D., Richardson, R. M. \& Sandiford, M. On the gravitational potential of the Earth's lithosphere. Tectonics 13, 929945 (1994).

45. Rajaonarison, T. A., Stamps, D. S. \& Naliboff, J. Role of Lithospheric Buoyancy Forces in Driving Deformation in East Africa From 3D Geodynamic Modeling. Geophys. Res. Lett. 48, e2020GL090483 (2021).

46. Coblentz, D. D. \& Sandiford, M. Tectonic stresses in the African plate: Constraints on the ambient lithospheric stress state. Geology 22, 831-834 (1994).

47. Craig, T. J., Jackson, J. A., Priestley, K. \& McKenzie, D. Earthquake distribution patterns in Africa: their relationship to variations in lithospheric and geological structure, and their rheological implications. Geophys. J. Int. 185, 403-434 (2011).

48. Stamps, D. S., laffaldano, G. \& Calais, E. Role of mantle flow in Nubia-Somalia plate divergence. Geophys. Res. Lett. 42, 2014GL062515 (2015).

49. Moucha, R. \& Forte, A. M. Changes in African topography driven by mantle convection. Nat. Geosci. 4, 707-712 (2011).

50. Jones, C. H., Sonder, L. J. \& Unruh, J. R. Lithospheric gravitational potential energy and past orogenesis: Implications for conditions of initial Basin and Range and Laramide deformation. Geology 26, 639-642 (1998).

51. Huerta, A. D. \& Harry, D. L. The transition from diffuse to focused extension: Modeled evolution of the West Antarctic Rift system. Earth Planet. Sci. Lett. 255, 133-147 (2007).

52. Bialas, R. W., Buck, W. R., Studinger, M. \& Fitzgerald, P. G. Plateau collapse model for the Transantarctic Mountains-West Antarctic Rift System: Insights from numerical experiments. Geology 35, 687-690 (2007).

53. Forsyth, D. \& Uyeda, S. On the Relative 
Importance of the Driving Forces of Plate Motion. Geophys. J. R. Astron. Soc. 43, 163200 (1975).

54. Richter, F. \& McKenzie, D. Simple plate models of mantle convection. J. Geophys. 44, 441-471 (1977).

55. Bird, P., Liu, Z. \& Rucker, W. K. Stresses that drive the plates from below: Definitions, computational path, model optimization, and error analysis. J. Geophys. Res. Solid Earth 113, (2008).

56. Conrad, C. P. \& Lithgow-Bertelloni, C. Influence of continental roots and asthenosphere on plate-mantle coupling. Geophys. Res. Lett. 33, 4 PP. (2006).

57. Flament, N., Gurnis, M. \& Müller, R. D. A review of observations and models of dynamic topography. Lithosphere 5, 189-210 (2013).

58. Hoggard, M. J., White, N. \& Al-Attar, D. Global dynamic topography observations reveal limited influence of large-scale mantle flow. Nat. Geosci. 9, 456-463 (2016).

59. Molnar, P., England, P. C. \& Jones, C. H. Mantle dynamics, isostasy, and the support of high terrain. J. Geophys. Res. Solid Earth 120, 2014JB011724 (2015).

60. Colli, L., Ghelichkhan, S. \& Bunge, H.-P. On the ratio of dynamic topography and gravity anomalies in a dynamic Earth. Geophys. Res. Lett. 43, 2016GL067929 (2016).

61. Morgan, W. J. Deep Mantle Convection Plumes and Plate Motions. AAPG Bull. 56, 203-213 (1972).

62. Buck, W. R. The role of magma in the development of the Afro-Arabian Rift System. Geol. Soc. Lond. Spec. Publ. 259, 43-54 (2006).

63. Blackburn, T. J. et al. Zircon U-Pb Geochronology Links the End-Triassic Extinction with the Central Atlantic Magmatic Province. Science 340, 941-945 (2013).

64. Renne, P. R. et al. The Age of Paraná Flood Volcanism, Rifting of Gondwanaland, and the Jurassic-Cretaceous Boundary. Science 258, 975-979 (1992).

65. Courtillot, V. E. \& Renne, P. R. On the ages of flood basalt events. Comptes Rendus Geosci. 335, 113-140 (2003).

66. van Summeren, J., Conrad, C. P. \& LithgowBertelloni, C. The importance of slab pull and a global asthenosphere to plate motions. Geochem. Geophys. Geosystems 13, (2012).

67. Kendall, J.-M. \& Lithgow-Bertelloni, C. Why is Africa rifting? Geol. Soc. Lond. Spec. Publ. 420, SP420.17 (2016).

68. Turcotte, D. L. \& Schubert, G. Geodynamics. (Cambridge University Press, 2014).
69. Billen, M. I. Modeling the Dynamics of Subducting Slabs. Annu. Rev. Earth Planet. Sci. 36, 325-356 (2008).

70. Taylor, B., Goodliffe, A. M. \& Martinez, F. How continents break up: Insights from Papua New Guinea. J. Geophys. Res. Solid Earth 104, 7497-7512 (1999).

71. Petersen, K. D. \& Buck, W. R. Eduction, extension, and exhumation of ultrahighpressure rocks in metamorphic core complexes due to subduction initiation. Geochem. Geophys. Geosystems 16, 2564 2581 (2015).

72. McClusky, S., Reilinger, R., Mahmoud, S., Ben Sari, D. \& Tealeb, A. GPS constraints on Africa (Nubia) and Arabia plate motions. Geophys. J. Int. 155, 126-138 (2003).

73. Karig, D. E. Origin and development of marginal basins in the western Pacific. J. Geophys. Res. 1896-1977 76, 2542-2561 (1971).

74. Tatsumi, Y., Otofuji, Y.-I., Matsuda, T. \& Nohda, S. Opening of the Sea of Japan backarc basin by asthenospheric injection. Tectonophysics 166, 317-329 (1989).

75. Brace, W. F. \& Kohlstedt, D. L. Limits on lithospheric stress imposed by laboratory experiments. J. Geophys. Res. Solid Earth 85, 6248-6252 (1980).

76. Coulomb, C. A. Essai sur une application des règles de maximis \& minimis à quelques problèmes de statique, relatifs à l'architecture. Memoires Math. L'Academie R. Sci. 7, (1773).

77. Scholz, C. H. The Mechanics of Earthquakes and Faulting. (Cambridge University Press, 2019).

78. Anderson, E. M. The dynamics of faulting. Oliver Boyd Edinb. LondonI963 (1948).

79. Byerlee, J. Friction of rocks. Pure Appl. Geophys. 116, 615-626 (1978).

80. Vardoulakis, I. Shear band inclination and shear modulus of sand in biaxial tests. Int. J. Numer. Anal. Methods Geomech. 4, 103-119 (1980).

81. Lecomte, E., Le Pourhiet, L. \& Lacombe, O. Mechanical basis for slip along low-angle normal faults. Geophys. Res. Lett. 39, (2012).

82. Wilks, K. R. \& Carter, N. L. Rheology of Some Continental Lower Crustal Rocks. Tectonophysics 182, 57-77 (1990).

83. Karato, S. \& Wu, P. Rheology of the Upper Mantle - a Synthesis. Science 260, 771-778 (1993).

84. Bürgmann, R. \& Dresen, G. Rheology of the Lower Crust and Upper Mantle: Evidence from Rock Mechanics, Geodesy, and Field Observations. Annu. Rev. Earth Planet. Sci. 
36, 531-567 (2008).

85. Karato, S. Deformation of Earth Materials: An Introduction to the Rheology of Solid Earth. (Cambridge University Press, 2008).

86. Daly, M. C., Chorowicz, J. \& Fairhead, J. D. Rift basin evolution in Africa: the influence of reactivated steep basement shear zones. Geol. Soc. Lond. Spec. Publ. 44, 309-334 (1989).

87. Ranalli, G. \& Yin, Z.-M. Critical stress difference and orientation of faults in rocks with strength anisotropies: the twodimensional case. J. Struct. Geol. 12, 10671071 (1990).

88. Morley, C. K. et al. Activation of rift oblique and rift parallel pre-existing fabrics during extension and their effect on deformation style: examples from the rifts of Thailand. $J$. Struct. Geol. 26, 1803-1829 (2004).

89. Kolawole, F. et al. Active Deformation of Malawi Rift's North Basin Hinge Zone Modulated by Reactivation of Preexisting Precambrian Shear Zone Fabric. Tectonics 37, 683-704 (2018).

90. Albaric, J., Déverchère, J., Petit, C., Perrot, J. \& Le Gall, B. Crustal rheology and depth distribution of earthquakes: Insights from the central and southern East African Rift System. Tectonophysics 468, 28-41 (2009).

91. Hamilton, W. Crustal extension in the Basin and Range Province, southwestern United States. Geol. Soc. Lond. Spec. Publ. 28, 155176 (1987).

92. Wilson, J. T. Did the Atlantic Close and then Re-Open? Nature 211, 676-681 (1966).

93. Buiter, S. J. H. \& Torsvik, T. H. A review of Wilson Cycle plate margins: A role for mantle plumes in continental break-up along sutures? Gondwana Res. 26, 627-653 (2014).

94. Petersen, K. D. \& Schiffer, C. Wilson cycle passive margins: Control of orogenic inheritance on continental breakup. Gondwana Res. 39, 131-144 (2016).

95. Busby, C. J. Birth of a plate boundary at ca. $12 \mathrm{Ma}$ in the Ancestral Cascades arc, Walker Lane belt of California and Nevada. Geosphere 9, 1147-1160 (2013).

96. Maurin, J.-C. \& Guiraud, R. Basement control in the development of the early cretaceous West and Central African rift system. Tectonophysics 228, 81-95 (1993).

97. Stein, S. et al. Insights from North America's failed Midcontinent Rift into the evolution of continental rifts and passive continental margins. Tectonophysics 744, 403-421 (2018).

98. Schiffer, C. et al. Structural inheritance in the
North Atlantic. Earth-Sci. Rev. 206, 102975 (2020).

99. Wheeler, W. H. \& Karson, J. A. Extension and subsidence adjacent to a 'weak' continental transform: An example from the Rukwa rift, East Africa. Geology 22, 625-628 (1994).

100. Osagiede, E. E. et al. Influence of zones of pre-existing crustal weakness on strain localization and partitioning during rifting: Insights from analogue modeling using high resolution 3D digital image correlation. Tectonics e2021TC006970 (2021) doi:10.1029/2021TC006970.

101. Kolawole, F., Phillips, T. B., Atekwana, E. A. \& Jackson, C. A.-L. Structural Inheritance Controls Strain Distribution During Early Continental Rifting, Rukwa Rift. Front. Earth Sci. 9, 670 (2021).

102. Ring, U., Schwartz, H. L., Bromage, T. G. \& Sanaane, C. Kinematic and sedimentological evolution of the Manyara Rift in northern Tanzania, East Africa. Geol. Mag. 142, 355-368 (2005).

103. Morley, C. K. Stress re-orientation along zones of weak fabrics in rifts: An explanation for pure extension in 'oblique' rift segments? Earth Planet. Sci. Lett. 297, 667-673 (2010).

104. Williams, J. N. et al. How Do Variably Striking Faults Reactivate During Rifting? Insights From Southern Malawi. Geochem. Geophys. Geosystems 20, 3588-3607 (2019).

105. Laó-Dávila, D. A., Al-Salmi, H. S., Abdelsalam, M. G. \& Atekwana, E. A. Hierarchical segmentation of the Malawi Rift: The influence of inherited lithospheric heterogeneity and kinematics in the evolution of continental rifts. Tectonics 34, 2399-2417 (2015).

106. Le Gall, B., Vétel, W. \& Morley, C. K. Inversion tectonics during continental rifting: The Turkana Cenozoic rifted zone, northern Kenya. Tectonics 24, TC2002 (2005).

107. Forsyth, D. W. Finite extension and lowangle normal faulting. Geology 20, 27-30 (1992).

108. Buck, W. R. Effect of lithospheric thickness on the formation of high- and lowangle normal faults. Geology 21, 933-936 (1993).

109. Lavier, L. L., Buck, W. R. \& Poliakov, A. N. B. Factors controlling normal fault offset in an ideal brittle layer. J. Geophys. Res. 105, 23431-23,442 (2000).

110. Kusznir, N. J. \& Park, R. G. The extensional strength of the continental lithosphere: its dependence on geothermal 
gradient, and crustal composition and thickness. Geol. Soc. Lond. Spec. Publ. 28, 35-52 (1987).

111. Heckenbach, E. L., Brune, S., Glerum, A. C. \& Bott, J. Is There a Speed Limit for the Thermal Steady-State Assumption in Continental Rifts? Geochem. Geophys. Geosystems 22, e2020GC009577 (2021).

112. Faleide, J. I. et al. Structure and Evolution of the Continental Margin off Norway and the Barents Sea. Episodes 31, 82-91 (2008).

113. Naliboff, J. \& Buiter, S. J. H. Rift reactivation and migration during multiphase extension. Earth Planet. Sci. Lett. 421, 58-67 (2015).

114. Foster, D. A. \& Gleadow, A. J. W. Structural framework and denudation history of the flanks of the Kenya and Anza Rifts, East Africa. Tectonics 15, 258-271 (1996).

115. Gupta, A. \& Scholz, C. H. A model of normal fault interaction based on observations and theory. J. Struct. Geol. 22, 865-879 (2000).

116. Cowie, P. A., Scholz, C. H., Edwards, M. \& Malinverno, A. Fault strain and seismic coupling on mid-ocean ridges. J. Geophys. Res. Solid Earth 98, 17911-17920 (1993).

117. Michas, G., Vallianatos, F. \& Sammonds, $P$. Statistical mechanics and scaling of fault populations with increasing strain in the Corinth Rift. Earth Planet. Sci. Lett. 431, 150163 (2015).

118. Weissel, J. K. \& Karner, G. D. Flexural uplift of rift flanks due to mechanical unloading of the lithosphere during extension. $J$. Geophys. Res. Solid Earth 94, 13919-13950 (1989).

119. Morley, C. K. Developments in the structural geology of rifts over the last decade and their impact on hydrocarbon exploration. Geol. Soc. Lond. Spec. Publ. 80, 1-32 (1995).

120. Goldsworthy, M. \& Jackson, J. Migration of activity within normal fault systems: examples from the Quaternary of mainland Greece. J. Struct. Geol. 23, 489-506 (2001).

121. Wernicke, B., Axen, G. J. \& Snow, J. K. Basin and Range extensional tectonics at the latitude of Las Vegas, Nevada. Geol. Soc. Am. Bull. 100, 1738-1757 (1988).

122. Cowie, P. A., Scholz, C. H., Roberts, G. P., Walker, J. P. F. \& Steer, P. Viscous roots of active seismogenic faults revealed by geologic slip rate variations. Nat. Geosci. 6, ngeo1991 (2013).

123. Gans, P. B. \& Gentry, B. J. Dike emplacement, footwall rotation, and the transition from magmatic to tectonic extension in the Whipple Mountains metamorphic core complex, southeastern California. Tectonics 35, 2016TC004215 (2016).

124. Escartín, J., Hirth, G. \& Evans, B. Effects of serpentinization on the lithospheric strength and the style of normal faulting at slowspreading ridges. Earth Planet. Sci. Lett. 151, 181-189 (1997).

125. Collettini, C. \& Sibson, R. H. Normal faults, normal friction? Geology 29, 927-930 (2001).

126. Tesei, T., Collettini, C., Carpenter, B. M., Viti, C. \& Marone, C. Frictional strength and healing behavior of phyllosilicate-rich faults. $J$. Geophys. Res. Solid Earth 117, (2012).

127. Hubbert, K. M. \& Rubey, W. W. Role of fluid pressure in mechanics of overthrust faulting: I. Mechanics of fluid-filled porous solids and its application to overthrust faulting. Geol. Soc. Am. Bull. 70, 115-166 (1959).

128. Axen, G. J. \& Selverstone, J. Stress state and fluid-pressure level along the Whipple detachment fault, California. Geology 22, 835-838 (1994).

129. Chiodini, G. et al. Carbon dioxide Earth degassing and seismogenesis in central and southern Italy. Geophys. Res. Lett. 31, L07615 (2004).

130. Davis, D., Suppe, J. \& Dahlen, F. A. Mechanics of fold-and-thrust belts and accretionary wedges. J. Geophys. Res. Solid Earth 88, 1153-1172 (1983).

131. Yuan, X. P., Olive, J.-A. \& Braun, J. Partially Locked Low-Angle Normal Faults in Cohesive Upper Crust. Tectonics 39, e2019TC005753 (2020).

132. Viti, C., Collettini, C., Tesei, T., Tarling, M. S. \& Smith, S. A. F. Deformation Processes, Textural Evolution and Weakening in Retrograde Serpentinites. Minerals 8, 241 (2018).

133. Lavier, L. L. \& Manatschal, G. A mechanism to thin the continental lithosphere at magma-poor margins. Nature 440, 324328 (2006).

134. Whitmarsh, R. B., Manatschal, G. \& Minshull, T. A. Evolution of magma-poor continental margins from rifting to seafloor spreading. Nature 413, 150-154 (2001).

135. Bayrakci, G. et al. Fault-controlled hydration of the upper mantle during continental rifting. Nat. Geosci. 9, 384-388 (2016).

136. Pérez-Gussinyé, M., Morgan, J. P., Reston, T. J. \& Ranero, C. R. The rift to drift transition at non-volcanic margins: Insights from numerical modelling. Earth Planet. Sci. Lett. 244, 458-473 (2006). 
137. Liu, Z. et al. Lateral coexistence of ductile and brittle deformation shapes magma-poor distal margins: An example from the West Iberia-Newfoundland margins. Earth Planet. Sci. Lett. 578, 117288 (2022).

138. Faulkner, D. R. et al. A review of recent developments concerning the structure, mechanics and fluid flow properties of fault zones. J. Struct. Geol. 32, 1557-1575 (2010).

139. Rowland, J. V. \& Sibson, R. H. Structural controls on hydrothermal flow in a segmented rift system, Taupo Volcanic Zone, New Zealand. Geofluids 4, 259-283 (2004).

140. Faulds, J. (ORCID:0000000173226543) \& Hinz, N. Favorable tectonic and structural settings of geothermal systems in the Great Basin region, western USA: Proxies for discovering blind geothermal systems. Proc. World Geotherm. Congr. Melb. Aust. 19-25 April 2015 (2015).

141. Omenda, P., Mangi, P., Ofwona, C. \& Mwangi, M. Country update report for Kenya 2015-2019. in Proceedings of World Geothermal Congress (2020).

142. Vidal, J. \& Genter, A. Overview of naturally permeable fractured reservoirs in the central and southern Upper Rhine Graben: Insights from geothermal wells. Geothermics 74, 5773 (2018).

143. Lee, H. et al. Massive and prolonged deep carbon emissions associated with continental rifting. Nat. Geosci. 9, 145-149 (2016).

144. Brune, S., Williams, S. E. \& Müller, R. D. Potential links between continental rifting, CO2 degassing and climate change through time. Nat. Geosci. 10, 941-946 (2017).

145. Muirhead, J. D. et al. Evolution of upper crustal faulting assisted by magmatic volatile release during early-stage continental rift development in the East African Rift. Geosphere 12, 1670-1700 (2016).

146. Lavier, L. L. \& Buck, W. R. Half graben versus large-offset low-angle normal fault: Importance of keeping cool during normal faulting. J. Geophys. Res. 107, 2122 (2002).

147. Behn, M. D. \& Ito, G. Magmatic and tectonic extension at mid-ocean ridges: 1 . Controls on fault characteristics. Geochem. Geophys. Geosystems 9, (2008).

148. Choi, E. \& Buck, W. R. Constraints on the strength of faults from the geometry of rider blocks in continental and oceanic core complexes. J. Geophys. Res. Solid Earth 117, B04410 (2012).

149. Olive, J.-A. \& Behn, M. D. Rapid rotation of normal faults due to flexural stresses: An explanation for the global distribution of normal fault dips. J. Geophys. Res. Solid Earth 119, 2013JB010512 (2014).

150. Olive, J.-A., Behn, M. D., Mittelstaedt, E., Ito, G. \& Klein, B. Z. The role of elasticity in simulating long-term tectonic extension. Geophys. J. Int. 205, 728-743 (2016).

151. Nagel, T. J. \& Buck, W. R. Channel flow and the development of parallel-dipping normal faults. J. Geophys. Res. Solid Earth 111, B08407 (2006).

152. Huismans, R. S. \& Beaumont, C. Depthdependent extension, two-stage breakup and cratonic underplating at rifted margins. Nature 473, 74-78 (2011).

153. Ruh, J., Tokle, L. \& Behr, W. SelfConsistent Grain Size Evolution controls Strain Localization during Rifting. (2021).

154. Hirth, G. \& Kohlstedt, D. L. Rheology of the upper mantle and the mantle wedge: $A$ view from the experimentalists. Geophys. Monogr. 138, 83-105 (2003).

155. Bickert, M., Lavier, L. \& Cannat, M. How do detachment faults form at ultraslow midocean ridges in a thick axial lithosphere? Earth Planet. Sci. Lett. 533, 116048 (2020).

156. Brune, S., Heine, C., Clift, P. D. \& PérezGussinyé, M. Rifted margin architecture and crustal rheology: Reviewing IberiaNewfoundland, Central South Atlantic, and South China Sea. Mar. Pet. Geol. 79, 257281 (2017).

157. Chenin, P., Schmalholz, S. M., Manatschal, G. \& Karner, G. D. Necking of the Lithosphere: A Reappraisal of Basic Concepts With Thermo-Mechanical Numerical Modeling. J. Geophys. Res. Solid Earth 0, (2018).

158. Brune, S., Popov, A. A. \& Sobolev, S. V. Modeling suggests that oblique extension facilitates rifting and continental break-up. J. Geophys. Res. 117, B08402 (2012).

159. Brune, S., Williams, S. E., Butterworth, N. P. \& Müller, R. D. Abrupt plate accelerations shape rifted continental margins. Nature 536, 201-204 (2016).

160. Ulvrova, M. M., Brune, S. \& Williams, S. Breakup Without Borders: How Continents Speed Up and Slow Down During Rifting. Geophys. Res. Lett. 46, 1338-1347 (2019).

161. Kneller, E. A., Johnson, C. A., Karner, G. D., Einhorn, J. \& Queffelec, T. A. Inverse methods for modeling non-rigid plate kinematics: Application to mesozoic plate reconstructions of the Central Atlantic. Comput. Geosci. 49, 217-230 (2012).

162. Whittaker, J. M., Williams, S. E. \& Müller, R. D. Revised tectonic evolution of the 
Eastern Indian Ocean. Geochem. Geophys. Geosystems 14, 1891-1909 (2013).

163. Leeder, M. R. \& Gawthorpe, R. L. Sedimentary models for extensional tiltblock/half-graben basins. Geol. Soc. Lond. Spec. Publ. 28, 139-152 (1987).

164. Burov, E. \& Cloetingh, S. Erosion and rift dynamics: new thermomechanical aspects of post-rift evolution of extensional basins. Earth Planet. Sci. Lett. 150, 7-26 (1997).

165. Burov, E. \& Poliakov, A. Erosion and rheology controls on synrift and postrift evolution: Verifying old and new ideas using a fully coupled numerical model. J. Geophys. Res.-Solid Earth 106, 16461-16481 (2001).

166. Bialas, R. W. \& Buck, W. R. How sediment promotes narrow rifting: Application to the Gulf of California. Tectonics 28, TC4014 (2009).

167. Buiter, S. J. H., Huismans, R. S. \& Beaumont, C. Dissipation analysis as a guide to mode selection during crustal extension and implications for the styles of sedimentary basins. J. Geophys. Res.-Solid Earth 113, B06406 (2008).

168. Olive, J.-A., Behn, M. D. \& Malatesta, L. C. Modes of extensional faulting controlled by surface processes. Geophys. Res. Lett. 41, 6725-6733 (2014).

169. Olive, J.-A., Malatesta, L. C., Behn, M. D. \& Buck, R. W. Sensitivity of rift tectonics to global variability in the efficiency of river erosion. Press PNAS (2022).

170. Andrés-Martínez, M., Pérez-Gussinyé, M., Armitage, J. \& Morgan, J. P. Thermomechanical Implications of Sediment Transport for the Architecture and Evolution of Continental Rifts and Margins. Tectonics 38, 641-665 (2019).

171. Theunissen, T. \& Huismans, R. S. LongTerm Coupling and Feedback Between Tectonics and Surface Processes During Non-Volcanic Rifted Margin Formation. J. Geophys. Res. Solid Earth 124, 12323-12347 (2019).

172. McKenzie, D. \& Bickle, M. J. The Volume and Composition of Melt Generated by Extension of the Lithosphere. J. Petrol. 29, 625-679 (1988).

173. White, R. \& McKenzie, D. Magmatism at rift zones: The generation of volcanic continental margins and flood basalts. $J$. Geophys. Res. Solid Earth 94, 7685-7729 (1989).

174. van Wijk, J. W., Huismans, R. S., ter Voorde, M. \& Cloetingh, S. a. P. L. Melt generation at volcanic continental margins: No need for a mantle plume? Geophys. Res.
Lett. 28, 3995-3998 (2001).

175. King, S. D. \& Anderson, D. L. Edge-driven convection. Earth Planet. Sci. Lett. 160, 289296 (1998).

176. Njinju, E. A., Stamps, D. S., Neumiller, K. \& Gallager, J. Lithospheric Control of Melt Generation Beneath the Rungwe Volcanic Province, East Africa: Implications for a Plume Source. J. Geophys. Res. Solid Earth 126, e2020JB020728 (2021).

177. Rooney, T. O., Nelson, W. R., Dosso, L., Furman, T. \& Hanan, B. The role of continental lithosphere metasomes in the production of HIMU-like magmatism on the northeast African and Arabian plates. Geology 42, 419-422 (2014).

178. Sparks, D. W. \& Parmentier, E. M. Melt extraction from the mantle beneath spreading centers. Earth Planet. Sci. Lett. 105, 368-377 (1991).

179. McKenzie, D. The generation and compaction of partially molten rock. J. Petrol. 25, 713-765 (1984).

180. Keller, T., May, D. A. \& Kaus, B. J. P. Numerical modelling of magma dynamics coupled to tectonic deformation of lithosphere and crust. Geophys. J. Int. 195, 1406-1442 (2013).

181. Havlin, C., Parmentier, E. M. \& Hirth, G. Dike propagation driven by melt accumulation at the lithosphere-asthenosphere boundary. Earth Planet. Sci. Lett. 376, 20-28 (2013).

182. Kendall, J.-M., Stuart, G. W., Ebinger, C. J., Bastow, I. D. \& Keir, D. Magma-assisted rifting in Ethiopia. Nature 433, 146-148 (2005).

183. Rowland, J. V., Wilson, C. J. N. \& Gravley, D. M. Spatial and temporal variations in magma-assisted rifting, Taupo Volcanic Zone, New Zealand. J. Volcanol. Geotherm. Res. 190, 89-108 (2010).

184. Mulibo, G. D. \& Nyblade, A. A. Mantle transition zone thinning beneath eastern Africa: Evidence for a whole-mantle superplume structure. Geophys. Res. Lett. 40, 3562-3566 (2013).

185. Dèzes, P., Schmid, S. M. \& Ziegler, P. A. Evolution of the European Cenozoic Rift System: interaction of the Alpine and Pyrenean orogens with their foreland lithosphere. Tectonophysics $\mathbf{3 8 9}, \quad \mathbf{1 - 3 3}$ (2004).

186. Gawthorpe, R. L. et al. Tectonosedimentary evolution of the Plio-Pleistocene Corinth rift, Greece. Basin Res. 30, 448-479 (2018).

187. Tregoning, P. et al. Estimation of current 
plate motions in Papua New Guinea from Global Positioning System observations. J. Geophys. Res. Solid Earth 103, 12181-12203 (1998).

188. Tesauro, M., Hollenstein, C., Egli, R., Geiger, A. \& Kahle, H.-G. Continuous GPS and broad-scale deformation across the Rhine Graben and the Alps. Int. J. Earth Sci. 94, 525-537 (2005).

189. Berglund, H. T. et al. Distributed deformation across the Rio Grande Rift, Great Plains, and Colorado Plateau. Geology 40, 23-26 (2012).

190. Gaina, C., Nasuti, A., Kimbell, G. S. \& Blischke, A. Break-up and seafloor spreading domains in the NE Atlantic. Geol. Soc. Lond. Spec. Publ. 447, SP447.12 (2017).

191. Hosseinpour, M., Müller, R. D., Williams, S. E. \& Whittaker, J. M. Full-fit reconstruction of the Labrador Sea and Baffin Bay. Solid Earth 4, 461-479 (2013).

192. Fazlikhani, H., Fossen, H., Gawthorpe, R. L., Faleide, J. I. \& Bell, R. E. Basement structure and its influence on the structural configuration of the northern North Sea rift. Tectonics 36, 1151-1177 (2017).

193. Miller, S. R., Baldwin, S. L. \& Fitzgerald, P. G. Transient fluvial incision and active surface uplift in the Woodlark Rift of eastern Papua New Guinea. Lithosphere 4, 131-149 (2012).

194. Jess, S. et al. Paleogene initiation of the Western Branch of the East African Rift: The uplift history of the Rwenzori Mountains, Western Uganda. Earth Planet. Sci. Lett. 552, 116593 (2020).

195. Globig, J. et al. New insights into the crust and lithospheric mantle structure of Africa from elevation, geoid, and thermal analysis. $J$. Geophys. Res. Solid Earth 121, 2016JB012972 (2016).

196. Baumann, T. S. \& Kaus, B. J. P. Geodynamic inversion to constrain the nonlinear rheology of the lithosphere. Geophys. J. Int. 202, 1289-1316 (2015).

197. Brune, S., Williams, S. E. \& Müller, R. D. Oblique rifting: the rule, not the exception. Solid Earth 9, 1187-1206 (2018).

198. Naliboff, J., Glerum, A., Brune, S., PéronPinvidic, G. \& Wrona, T. Development of 3-D Rift Heterogeneity Through Fault Network Evolution. Geophys. Res. Lett. 47, e2019GL086611 (2020).

199. Duretz, T., de Borst, R. \& Le Pourhiet, L. Finite Thickness of Shear Bands in Frictional Viscoplasticity and Implications for Lithosphere Dynamics. Geochem. Geophys.
Geosystems 20, 5598-5616 (2019).

200. Zwaan, F., Schreurs, G. \& Rosenau, M. Rift propagation in rotational versus orthogonal extension: Insights from 4D analogue models. J. Struct. Geol. 103946 (2019) doi:10.1016/j.jsg.2019.103946.

201. Molnar, N. E., Cruden, A. R. \& Betts, P. G. Unzipping continents and the birth of microcontinents. Geology 46, 451-454 (2018). 